Chapter 5

\title{
Normal Distribution and Plasticity of Serotonin Receptors after Spinal Cord Injury and Their Impacts on Motor Outputs
}

\author{
Mengliang Zhang \\ Additional information is available at the end of the chapter \\ http://dx.doi.org/10.5772/63759
}

\begin{abstract}
Following spinal cord injury (SCI) a series of anatomical and functional plastic changes occurinthespinalcord, includingreorganization of thespinalneuronalnetwork, alteration of properties of interneurons and motoneurons as well as up- or down-regulation of different neurotransmitter receptors. In mammalian spinal cord, one of the important neurotransmitters, serotonin (5-HT), plays an essential role in modulating sensory, motor and autonomic functions. Following SCI, especially complete spinal cord lesion, the descending supply of 5-HT is lost. As a consequence different 5-HT receptors undergo variant degrees of plastic changes.

In this chapter I have systematically reviewed the distribution of different 5 -HT receptors in the spinal cord and their plastic changes following SCI where applicable. In addition, the plastic changes of 5-HT supplying system in reaction to SCI have also been reviewed. These results indicate that 5 -HT receptors are important factors not only for modulation of normal motor function, their plastic changes are also critical for motor functional recovery and, quite often, for the development of certain pathological states after SCI. Pharmacological and/or genetic intervention of selected 5-HT receptors and/or intrinsic 5-HT producing system in the spinal cord may pave new ways for the restoration of motor functions after SCI.
\end{abstract}

Keywords: monoamine, monoamine receptor, spinal cord, motor control, intraspinal 5-HT cell 


\section{Introduction}

Spinal cord injury (SCI) is a devastating condition with an incidence of $10-83$ per million people per year worldwide according to statistical data from different countries [1]. It leads to an extensive and usually irreversible loss of sensory functions, voluntary motor control, and autonomic functions below injury level. A variety of primary and secondary complications occur depending on the severity of the injury and time course of its development. These symptoms may involve different systems, manifesting as, e.g., paralysis, spasticity, neuropathic pain, pulmonary and cardiovascular problems, osteoporosis, anemia, pressure ulcers, bladder and bowel problems, and sexual dysfunction [2-8]. Currently, there is no cure for SCI and thus improving quality of life, such as restoration of partial motor and sensory functions, has become a priority for setting up the treatment strategy. The primary cause of these problems is the loss of both descending and ascending projecting pathways in the spinal cord. The descending pathways include direct motor-initiating pathways, such as cortical spinal tracts, and modulatory pathways, such as serotonergic, dopaminergic, and noradrenergic pathways. These monoaminergic systems are so important that in either acute or chronic SCI direct stimulation of the receptors of these monoamines with drugs could regain locomotor activity in animals [9-17]. Thus, restoring the function of monoaminergic systems has become a key strategy to restore motor function and ameliorate secondary symptoms [18-23].

So far a great number of studies have been focusing on the serotonergic system in SCI. In the mammalian spinal cord, serotonin (5-HT) originates mainly in the raphe nuclei of the brainstem and plays an important role in modulating sensory, motor, and autonomic function [2427]. Following SCI, especially complete spinal cord lesion, the descending supply of 5-HT is lost and as a consequence different 5 -HT receptors undergo variant degrees of plastic changes $[22,28-36]$. In addition, a potential intraspinal 5-HT-producing system in the spinal cord, i.e., aromatic L-amino acid decarboxylase (AADC) cells, also undergoes plastic changes to increase their potency to produce 5-HT from its precursor [37-40]. Although these plastic changes may induce pathological symptoms such as spasticity and chronic central pain [34, 41, 42], they are essential for spinal function recovery (for review see [43-45]). In this chapter, I will make a systematic review according to up-to-date literature related to the distribution and plastic changes of 5-HT receptors in the spinal cord in normal or SCI states with a note on the intraspinal 5-HT-producing cells.

\section{5-HT in the spinal cord in health}

In mammals, including humans, 5-HT axons in the spinal cord almost exclusively originate from the brainstem raphe nuclei [46-49]. Their terminals are distributed in all parts of the gray matter at all levels of the spinal cord [50,51]. The cell bodies with descending 5-HT projections are located in the caudal part of the raphe nuclei, which include the raphe magnus, raphe obscurus, raphe pallidus, ventral lateral medulla, and the area postrema [52]. In the spinal cord, 5-HT projecting fibers descend in the white matter through two different routes: one with 
fibers from the raphe magnus in the dorsal part of the lateral funiculus which terminates mainly in the dorsal horn, and the other with fibers from raphe obscurus and raphe pallidus in the ventral funiculus which terminates mainly in the ventral horn and the intermediate zone.

In addition to the descending projecting system, there are indeed 5-HT neurons in the spinal cord although in normal states their contribution of 5-HT can be ignored. So far a small number of intraspinal 5-HT neurons have been reported in macaque monkey (ca. 150 cells per monkey [53]), rat (3-9 cells per rat [54, 55]), and mouse [51]. In the rat spinal cord, 5-HT cells were distributed in different parts of the spinal cord with the exception of cervical segments; in the monkey spinal cord most of the cells were observed in the cervical segments with a small number in other segments; whereas in the mouse spinal cord they were exclusively located in the sacral segments. In the rat spinal cord, the 5-HT cells were found to be located in laminae VII and $X$ in the gray matter, whereas in monkey and mouse spinal cord they were exclusively found in lamina $X$.

Serotonin in the spinal cord plays an important role in sensory information processing, motor control, and autonomic function. Traditionally, it is hypothesized that 5-HT in the spinal cord exerts its effects by inhibiting sensory systems and facilitating motor systems [56]. However, now it is known that the effects of 5-HT are very complicated both in sensory and motor aspects. In sensory aspect, 5-HT not only has antinociceptive but also pronociceptive effects (e.g., $[57,58])$. In motor aspect, except for facilitating motor output, 5-HT also inhibits motor behavior (e.g., $[59,60])$. The different functions that 5-HT exert at different circumstances depend on many factors, such as the brainstem origins of the descending projections, the termination localizations of these fibers in the spinal cord, and the activation states of its different receptors.

\section{5-HT receptors in the spinal cord in health}

The diverse functions of 5-HT in the spinal cord are achieved through the activation of different 5-HT receptors. As seen in Table 1, seven families (or types) and at least 14 subfamilies (or subtypes) of 5-HT receptors have been identified so far [61]. In these seven families, with exception of 5-HT3 receptors that are ligand-gated ion channels, all other families are $\mathrm{G}$ protein-coupled receptors [62]. To better understand the diversity of 5-HT functions, it is fundamentally important to have the knowledge of the anatomical localizations of different 5-HT receptors in the spinal cord. A majority, though not all, of 5-HT receptor subfamilies have been found to be expressed in the spinal cord (for reviews see [63, 64]). Here, I will make a systematic review of these receptors in terms of their cellular as well as subcellular localizations in the spinal cord based on available data. One should keep in mind that due to the existence of a great number of splices and editing variants for several 5-HT receptors, a greater degree of operational diversity could be expected, though this issue is not the focus of the present review. 


\begin{tabular}{|c|c|c|c|c|c|}
\hline $\begin{array}{l}\text { Receptor } \\
\text { family } \\
\text { (year of } \\
\text { molecular } \\
\text { gene } \\
\text { clone)* }\end{array}$ & $\begin{array}{l}\text { Receptor } \\
\text { subfamily } \\
\text { (year of } \\
\text { molecular } \\
\text { gene clone)* }\end{array}$ & $\begin{array}{l}\text { Expression in } \\
\text { the spinal cord }\end{array}$ & $\begin{array}{l}\text { Functions at } \\
\text { normal states }\end{array}$ & $\begin{array}{l}\text { Expression } \\
\text { changes } \\
\text { following } \\
\text { SCI }\end{array}$ & $\begin{array}{l}\text { Functions at } \\
\text { SCI states }\end{array}$ \\
\hline \multirow[t]{4}{*}{ 5-HT1 } & 1A (1987) & $\begin{array}{l}\text { Primary afferent } \\
\text { fibers in dorsal } \\
\text { horn [66]; neuronal } \\
\text { somata in } \\
\text { different } \\
\text { laminae of } \\
\text { gray matter } \\
\text { [31,69]; } \\
\text { axon initial } \\
\text { segments [31,71]; }\end{array}$ & $\begin{array}{l}\text { Antinociception [73,76]; } \\
\text { pronociception [77]; } \\
\text { increases } \\
\text { motoneuron } \\
\text { excitability [60]; } \\
\text { induces central } \\
\text { fatigue [81] }\end{array}$ & $\begin{array}{l}\text { Upregulation } \\
\text { at least to } \\
30 \text { days after } \\
\text { SCI }[28,31]\end{array}$ & $\begin{array}{l}\text { Promotes motor } \\
\text { functional } \\
\text { recovery } \\
{[13,14,172]}\end{array}$ \\
\hline & 1B (1992) & $\begin{array}{l}\text { Primary afferent } \\
\text { fibers in } \\
\text { dorsal horn } \\
\text { [83]; neuronal } \\
\text { somata at } \\
\text { least in } \\
\text { intermediate } \\
\text { zone [38] }\end{array}$ & $\begin{array}{l}\text { Antinociception [72]; } \\
\text { autoreceptor [89]; } \\
\text { inhibits activity } \\
\text { of AADC cells } \\
\text { [38] }\end{array}$ & -- & $\begin{array}{l}\text { Inhibits mono- } \\
\text { and polysynaptic } \\
\text { reflexes } \\
{[99,174]}\end{array}$ \\
\hline & 1D (1991) & $\begin{array}{l}\text { Primary afferent } \\
\text { fibers in } \\
\text { dorsal horn } \\
\text { [92]; gamma } \\
\text { motoneurons } \\
\text { in ventral } \\
\text { horn [94] }\end{array}$ & $\begin{array}{l}\text { Antinociception, [93]; } \\
\text { modulates } \\
\text { proprioceptive } \\
\text { circuits } \\
{[94]}\end{array}$ & -- & $\begin{array}{l}\text { Inhibits } \\
\text { polysynaptic } \\
\text { reflex [95]?? }\end{array}$ \\
\hline & $\begin{array}{l}1 \mathrm{E}(1992) \\
1 \mathrm{~F}(1993)\end{array}$ & $\begin{array}{l}\text {-- } \\
\text { gubstantia } \\
\text { of spinalinosa } \\
\text { dorsal horn } \\
{[98]}\end{array}$ & $\begin{array}{l}-- \\
\text { Antinociception } \\
{[101,102] ? ?}\end{array}$ & -- & $\begin{array}{l}\text {-- } \\
\text { Inhibits } \\
\text { polysynaptic } \\
\text { reflex [99]?? }\end{array}$ \\
\hline 5-HT2 & 2A (1988) & $\begin{array}{l}\text { Different laminae } \\
\text { of the spinal } \\
\text { gray matter } \\
\text { but largely in } \\
\text { the superficial } \\
\text { dorsal horn } \\
\text { and lamina IX }\end{array}$ & $\begin{array}{l}\text { Pronociceptive }[57,112] \\
\text { antinociceptive }[115] ; \\
\text { excites motoneuron } \\
\text { [117]; facilitates } \\
\text { micturition reflex } \\
\text { [119]; facilitates } \\
\text { sexual behavior }\end{array}$ & $\begin{array}{l}\text { Upregulation } \\
{[32,33,35]}\end{array}$ & $\begin{array}{l}\text { Locomotor } \\
\text { functional recovery } \\
{[12,14,43] ; 5-H T} \\
\text { supersensitivity } \\
\text { and muscle spasm } \\
\text { [42] }\end{array}$ \\
\hline
\end{tabular}




\begin{tabular}{|c|c|c|c|c|c|}
\hline $\begin{array}{l}\text { Receptor } \\
\text { family } \\
\text { (year of } \\
\text { molecular } \\
\text { gene } \\
\text { clone)* }\end{array}$ & $\begin{array}{l}\text { Receptor } \\
\text { subfamily } \\
\text { (year of } \\
\text { molecular } \\
\text { gene clone)* }\end{array}$ & $\begin{array}{l}\text { Expression in } \\
\text { the spinal cord }\end{array}$ & $\begin{array}{l}\text { Functions at } \\
\text { normal states }\end{array}$ & $\begin{array}{l}\text { Expression } \\
\text { changes } \\
\text { following } \\
\text { SCI }\end{array}$ & $\begin{array}{l}\text { Functions at } \\
\text { SCI states }\end{array}$ \\
\hline & & {$[104,107,108]$} & {$[120,121]$} & & \\
\hline & 2B (1992) & $\begin{array}{l}\text { Dorsal horn } \\
\text { (probably primary } \\
\text { afferent fibers) [109] }\end{array}$ & $\begin{array}{l}\text { Pronociception } \\
{[109,124,126]}\end{array}$ & $\begin{array}{l}\text { Constitutive } \\
\text { activation [182] }\end{array}$ & $\begin{array}{l}\text { Motoneuron } \\
\text { hyperexcitability } \\
\text { and muscle spasm } \\
\text { [182] }\end{array}$ \\
\hline & $\begin{array}{l}\text { 2C (1988) } \\
\text { (Named 1C } \\
\text { before 1993) }\end{array}$ & $\begin{array}{l}\text { Different } \\
\text { laminae of the } \\
\text { spinal gray } \\
\text { matter }[36,104,107]\end{array}$ & $\begin{array}{l}\text { Pronociception } \\
{[57,112] ;} \\
\text { antinociception } \\
{[96,115,133] ;} \\
\text { induces long-lasting } \\
\text { amplification of } \\
\text { spinal reflexes } \\
{[73,134] \text {; inhibits }} \\
\text { micturition reflex } \\
{[127,138]}\end{array}$ & $\begin{array}{l}\text { Constitutive } \\
\text { activation [34,182]; } \\
\text { upregulation } \\
{[22,36,177]}\end{array}$ & $\begin{array}{l}\text { Motor functional } \\
\text { recovery [34,182]; } \\
\text { 5-HT supersensitivity, } \\
\text { motoneuron } \\
\text { hyperexcitability, } \\
\text { and muscle spasm } \\
{[34,42,182]}\end{array}$ \\
\hline 5-HT3 & $\begin{array}{l}\text { 3A (1991) } \\
\text { 3B (1999) } \\
\text { 3C (2003) } \\
\text { 3D (2003) } \\
\text { 3E (2003) } \\
{[62,139]}\end{array}$ & $\begin{array}{l}\text { Different laminae } \\
\text { of the spinal } \\
\text { gray matter } \\
{[107,142]}\end{array}$ & $\begin{array}{l}\text { Antinociception [145,146]; } \\
\text { pronociception [149]; } \\
\text { mediates tail-flick } \\
\text { reflexes [117]; } \\
\text { inhibits bladder } \\
\text { function [152] }\end{array}$ & -- & $\begin{array}{l}\text { Promotes motor } \\
\text { function recovery [151] }\end{array}$ \\
\hline 5-HT4 (1995) & & $\begin{array}{l}\text { Ventral horn, } \\
\text { some sympathetic } \\
\text { neurons [153] }\end{array}$ & Pronociception [154] & -- & -- \\
\hline 5-HT5 & 5A (1994) & $\begin{array}{l}\text { Dorsal horn, } \\
\text { intermediate } \\
\text { lateral nucleus, } \\
\text { and Onuf's } \\
\text { nucleus [110,156] }\end{array}$ & $\begin{array}{l}\text { Antinociception }[58,157] \\
\text { autonomic and } \\
\text { micturition control } \\
{[156]}\end{array}$ & -- & -- \\
\hline & 5B (1993) & -- & -- & -- & -- \\
\hline 5-HT6 (1993) & & $\begin{array}{l}\text { Different laminae } \\
\text { of the spinal } \\
\text { gray matter [159] }\end{array}$ & Pronociception [160] & -- & -- \\
\hline 5-HT7 (1993) & & $\begin{array}{l}\text { Dorsal horn, } \\
\text { intermediate } \\
\text { zone, and } \\
\text { ventral horn }\end{array}$ & $\begin{array}{l}\text { Pronociception [164-166]; } \\
\text { promotes locomotion }\end{array}$ & & $\begin{array}{l}\text { Promotes } \\
\text { locomotor } \\
\text { functional }\end{array}$ \\
\hline
\end{tabular}






Table 1. 5-HT receptors in the spinal cord and plastic changes following SCI.

\subsection{5-HT1 receptors}

As listed in Table 1, 5-HT1 receptors include five subfamilies: 1A, 1B, 1D, 1E, and 1F. Although all of these receptors have been detected in the brain by different techniques [65], there is no report to my knowledge demonstrating the expression of 5-HT1E receptors in the spinal cord. In addition, the evidence of the existence of 5-HT1F in the spinal cord is mainly from physiological experiments. Nonetheless, I will describe 5-HT1A, 1B, 1D, and 1F in the spinal cord according to the available data.

5-HT1A receptors: Data from both autoradiographic (radioligand binding) and immunohistochemical experiments have demonstrated the presence of 5-HT1A receptors in different regions of the spinal gray matter across different spinal segments in rats [31, 66-69]. 5-HT1A receptor binding sites were predominantly seen in the dorsal horn especially laminae I and II [67], where they were partly located in the primary afferent fibers [66]. In autoradiographic images, it is difficult to identify the components located in cell bodies; however, with immunohistochemistry with a 5-HT1A antibody generated from an intracellular epitope, it was clear that 5-HT1A receptors were expressed in cell bodies in the spinal cord [31]. The immunolabeled cell bodies were located in different spinal regions in the gray matter including the dorsal horn, intermediate zone, and ventral horn [31, 69, 70]. In addition, using a different 5-HT1A antibody generated from an extracellular epitope, the receptors were also shown to be present in the axon hillock [31, 71]. There are no studies to investigate 5-HT1A receptor localization at an ultrastructural level and therefore no data available for their subcellular distribution.

It is commonly believed that 5-HT1A receptors exert an inhibitory effect in sensory information transmission including nociception in the spinal dorsal horn (e.g., [72-76]). For example, in mice intrathecal injection of 5 -HT1A receptor agonist 8 -hydroxy-2-(di- $n$-propylamino) tetralin (8-OH-DPAT) could inhibit the tail-flicks induced by noxious radiant heat [72]. In neonatal rat spinal cord in vitro experiments, Hochman et al. [73] showed that 8-OH-DPAT depressed evoked excitatory postsynaptic potentials (EPSPs) in the deep dorsal horn neurons, whereas 5-HT1A receptor antagonist WAY-100635 (N-[2-[4-(2-methoxyphenyl)-1- 
piperazinyl]ethyl]-N-(2-pyridyl)cyclohexanecarboxamide) facilitated evoked EPSPs. Data from the same group also indicated that the activation of 5-HT1A receptors facilitated longterm depression in the dorsal horn neurons. However, the effects of 5-HT1A receptors in the dorsal horn are not always inhibitory. For example, the activation of 5-HT1A receptors has been reported to facilitate nociceptive [77, 78] and itch transmission [79], and to induce spontaneous tail-flicks [80].

As 5-HT1A receptors have been found to be present both at the neuronal somata and the axon initial segments in spinal ventral horn neurons, including motoneurons [31], it is speculated that 5-HT1A receptors may have heterogeneous functions on motor outputs, i.e., both excitatory and inhibitory $[59,60]$. Indeed, using a turtle spinal cord, slice preparation, and intracellular recording technique, Perrier and Cotel [60] demonstrated that the activation of 5HT1A receptors by 8-OH-DPAT induced an increased excitability in a large fraction (9/11) of sampled motoneurons; whereas in a small fraction of motoneurons (2/11) 8-OH-DPAT gave a hyperpolarizing effect. Subsequent data from the same research group have demonstrated that the inhibitory effect was due to the activation of extrasynaptic 5-HT1A receptors located at the axon initial segments, a mechanism supposed to underlie central fatigue [81, 82].

5-HT1B receptors: To the best of my knowledge, there are no systematic immunohistochemical studies on the distribution of 5-HT1B receptors in the spinal cord. Previous studies using autoradiography have demonstrated that 5-HT1B receptors did not have any dominant expression region in the spinal gray matter although the intermediate zone seemed to dwell slightly higher labeled profiles $[67,68]$. Although it is difficult to differentiate labeled cell bodies from nerve fibers with autoradiography, results from studies using other methods including lesion, pharmacology, and reverse transcription polymerase chain reaction (RTPCT) indicated the existence of this receptor subfamily both at presynaptic (primary afferent fibers) [83] and postsynaptic locations (motoneurons) [84, 85]. Recently by using immunohistochemistry, Wienecke et al. [38] have found that 5-HT1B receptors were indeed expressed in the cell bodies at least in the intermediate zone in the rat spinal cord.

Similar to 5-HT1A receptors, a major role of 5-HT1B receptors is inhibition in sensory transmission, especially nociception [72, 86, 87]. For example, Eide et al. [72] showed that in mice intrathecal injection of 5-HT1B receptor antagonist RU-24969 (5-methoxy-3(1,2,3,6tetrahydropyridin-4-yl)- $1 H$-indole) induced a significant increase of tail-flick latencies. Another role of 5-HT1B receptors is to inhibit the release of 5-HT from its fibers via autoreceptor mechanism. Although both 5-HT1A and 1B receptors have been demonstrated to be autoreceptors in the brain, in the spinal cord it is most likely that 5-HT1B receptors play a more important role than 5-HT1A receptors in controlling the release of 5-HT from 5-HT fiber terminals [88-90]. Thus, Brown et al. [89] using rat spinal cord synaptosomes preparation showed that the 5-HT1B receptor agonists 1-( $m$-trifluoromethylphenyl)piperazine and 1-(mchlorophenyl) piperazine concentration-dependently decreased $[3 H] 5-H T$ release. In addition, 5-HT1B receptors could also inhibit the production of 5-HT from AADC cells in the spinal cord through feed-forward mechanism so that the AADC cells do not produce 5-HT in normal physiological states [38]. Another function of 5-HT1B receptors, as noted in mice, is to delay 
the maturation of $\gamma$-aminobutyric acid (GABA) phenotype in spinal cord during its development [91].

5-HT1D receptors: Data concerning the anatomical localization of 5-HT1D receptors in the spinal cord are relatively poor. The available data indicate that 5-HT1D receptors exist both in the dorsal and the ventral horn. Using immunohistochemistry, 5-HT1D receptors were found to be expressed in the primary afferent fibers in the superficial dorsal horn of the rat spinal cord $[92,93]$. At the ultrastructural level, 5-HT1D receptors in the spinal cord dorsal horn were found to be localized exclusively within dense core vesicles of synaptic terminals and not the plasma membrane [92]. Using in situ hybridization and transgenic mouse model, Enjin et al. [94] found that 5-HT1D receptors were specifically expressed in $\gamma$ motoneurons in the ventral horn as well as in some proprioceptive sensory neurons in different spinal regions which were coexpressed with parvalbumin (used as a proprioceptive neuronal marker in the study).

The available data indicate an effect of 5-HT1D receptors in the suppression of sensory, especially nociceptive, information transmission [58, 93, 95]. However, different results were also present. For example, in a formalin-induced hindpaw pain model, Jeong et al. [96] showed that the 5-HT1D receptor agonist GR-46611 (3-[3-(2-dimethylaminoethyl)-1H-indol-5-yl]-N-(4methoxybenzyl)acrylamide) did not suppress the formalin-induced flinching responses and the 5-HT1D receptor antagonist BRL-15572 (3-(4-(4-chlorophenyl)piperazin-1-yl)-1,1-diphenyl-2-propanol) failed to reverse the antinociceptive effects of 5-HT. Other functions of 5-HT1D receptors include, e.g., depressing the spinal monosynaptic reflex induced by endogenously released 5-HT [97], and shaping proprioceptive circuits to receive and relay accurate sensory information in the spinal cord motor network [94]. In addition, since 5-HT1D receptors were expressed in $\gamma$, but not $\alpha$, motoneurons, they could be used as a marker to identify $\gamma$ motoneurons in the spinal cord [94].

5-HT1F receptors: To my knowledge, there is no systematic investigation concerning the expression of 5-HT1F receptors in the spinal cord of any species. However, there are indeed some pieces of evidence from studies using radioligand or physiological technique indicating that this receptor subfamily is present in the spinal cord dorsal horn. Castro et al. [98] used $[3 \mathrm{H}]$ sumatriptan as a radioligand in the presence of suitable concentrations of 5-carboxamidotryptamine (5-CT) to define 5-HT1F receptors in the human spinal cord, and they found significant levels of binding sites in substantia gelatinosa in the cervical spinal cord. However, because 5-CT is not a specific 5-HT1F agonist, the data cannot be taken as granted. Using an in vitro sacrocaudal spinal cord preparation from spinal transected rats, Murray et al. [99] showed that the EPSPs and associated long polysynaptic reflexes were consistently inhibited by 5-HT1F-specific agonist LY-344864 ( $N$-[(3R)-3-(dimethylamino)-2,3,4,9-tetrahydro- $1 H$ carbazol-6-yl]-4-fluorobenzamide), indicating the existence of 5-HT1F in the spinal cord. However, the exact locations of these receptors are yet to be determined.

Due to the lack of related anatomical data, it is difficult to unveil the functions of 5-HT1F in the spinal cord. Considering that $5-\mathrm{HT} 1 \mathrm{~F}$ receptors are expressed in the trigeminal and spinal dorsal root ganglia [100] and their agonists have been used to treat migraine [101, 102], it is most likely that this receptor subfamily exerts an antinociceptive effect in spinal cord. 


\section{2. $5-\mathrm{HT} 2$ receptors}

As listed in Table 1, 5-HT2 receptors include three subfamilies, i.e., 5-HT2A, 2B, and 2C. Before 1993, 5-HT2C receptors were named 5-HT1C receptors [103]. By using different experimental techniques including autoradiography, in situ hybridization, Western blot and immunohistochemistry all these three receptor subfamilies have been detected in the spinal cord in different species [104-109] although 5-HT2C subfamily is probably not expressed in cat spinal cord [105]. 5-HT2A and 2C receptors are likely among the most thoroughly investigated 5-HT receptors in the spinal cord due to their important functions in both sensory information processing and motor control.

5- $H$ T2A receptors: Using various techniques, the existence of 5-HT2A receptors has been confirmed at both mRNA and protein level in the spinal cord of different species [104-108, 110]. By using polymerase chain reaction (PCR) together with Southern hybridization technique, Helton et al. [105] showed that spinal cord tissues from rat, cat, monkey, and human contained 5-HT2A receptor mRNAs. By using in situ hybridization, Pompeiano et al. [104] showed that 5-HT2A receptor mRNAs were present at intermediate density in the ventral horn. This distribution pattern has been confirmed with immunohistochemistry [106, 108]. Doly et al. [108] systematically investigated the distribution of 5-HT2A receptor immunoreactivity in rat spinal cord and the results indicated that 5-HT2A receptors were distributed in all the spinal segments with a similar immunolabeling pattern. The most prominent labeling was found in lamina IX, where many, but not all, motoneurons were labeled. At lumbar five to six level, 5HT2A receptors were densely expressed in Onuf's nucleus that contains the motoneurons innervating pelvic striated muscles controlling sexual behavior and micturition [110]. Another region with dense immunolabeling was lamina II. The remaining laminae of the gray matter displayed a weak to moderate labeling. Doly et al. [108] also examined the subcellular localization of 5-HT2A receptors in laminae II and IX and they demonstrated that most immunolabeled profiles were postsynaptic, i.e., dendrites and cell somata, although a small number of axons and axon terminals were also labeled. The immunoreactive product was localized mainly on the plasma membrane where synaptic specifications were lacking.

The localization of 5-HT2A receptors in the neurons in both the spinal dorsal and ventral horn endows their functions in both sensory information transmission and motor control. For the sensory information modulation, evidence to date largely favors in their pronociceptive role [57, 111-114]. For example, Kjørsvik et al. [112] showed that in formalin-induced pain model, intrathecal injection of DOI (( \pm )-2,5-dimethoxy-4-iodoamphetamine hydrochloride), a 5HT2A/2C receptor agonist, augmented nociceptive response in rats. This effect could be completely abolished when ketanserin (a 5-HT-2A receptor antagonist) was coadministrated. Rahman et al. [57] investigated the effects of DOI, ketanserin, and ritanserin (another 5-HT2A/ $2 \mathrm{C}$ antagonist) on the evoked responses of dorsal horn neurons to electrical, mechanical, and thermal stimulation, and found that the activation of 5-HT2A receptors facilitated the spinal nociceptive transmission under normal physiological states. However, there is also evidence indicating that 5-HT2A receptors exert an antinociceptive effect [115, 116]. For example, using a rat spinal cord slice preparation Xie et al. [115] found that bath application of 5-HT increased the frequency of spontaneous inhibitory postsynaptic currents in GABAergic and 
glycinergic neurons in substantia gelatinosa. TCB-2 (4-bromo-3,6-dimethoxybenzocyclobuten-1-yl)methylamine hydrobromide), a 5-HT2A receptor agonist, could mimic the 5-HT effect, and ketanserin could partially inhibit the effect of 5-HT and completely inhibit the effect of TCB-2.

It is not surprising that 5-HT2A receptors play a significant role in motor control considering their intensive expression in ventral horn motoneurons. Indeed, direct stimulation of 5HT2 receptors in motoneurons in vivo with selective 5-HT2 receptor agonist DOI or DOM (2,5dimethoxy-alpha,4-dimethylbenzene ethamine hydrochloride) produced dose-related back muscle contractions and wet dog shakes which could be markedly attenuated by ritanserin, ketanserin, or mianserin, suggesting an effect from 5-HT2A receptors [117]. Their direct facilitating effect on spinal motoneurons was also evidenced by application of DOI in rat spinal cord in vitro experiments [118]. In addition, pharmacological experiments showed that 5HT2A receptor activation facilitated micturition reflex and activated the external urethral sphincter in female rats [119], whereas in both male and female rats 5-HT2A receptors seemed to involve sexual behavior [120,121].

5-HT2B receptors: In comparison with 5-HT2A and 5-HT2C, 5-HT2B receptors in the spinal cord have been less investigated and the available data are inconsistent. Using in situ hybridization expression of 5-HT2B receptors was not found in rat spinal cord and even brain [104]. However, using several other techniques, the receptors have been detected in the spinal cord. Thus, using reverse transcription polymerase chain reaction (RT-PCR) 5-HT2B receptor mRNAs have been detected in spinal cord tissue in many different species including rat, cat, monkey, and human [105]. Using microarray global gene expression technique [122] and immunohistochemistry [123], 5-HT2B receptors have been detected in the rat spinal cord motoneurons. In addition, using Western blot it was shown that the receptor proteins were also present in the dorsal part of the spinal cord [109]. Considering that with Western blot and immunohistochemistry 5-HT2B receptors have been demonstrated to be expressed in the dorsal root ganglia $[109,124]$, their expression in the spinal dorsal horn is likely originating from the primary afferent fibers from the dorsal root ganglia, although it cannot be excluded that they might be also expressed in neuronal somata (e.g., [125]).

It is presumable that 5-HT2B receptors are largely related with sensory information transmission considering their localization in dorsal root ganglia and dorsal horn. Thus, evidence from a few studies related to 5-HT2B receptor functions in the spinal cord favors that the receptors are responsible for facilitating mechanical hyperalgesia, tactile allodynia, and nociception $[109,124,126]$. Studies concerning the receptors' motor function are rare. One study showed that 5-HT2B receptors likely increased urethral smooth muscle tone since the 5-HT2B receptor antagonist RS-127445 (3-(4-(4-chlorophenyl)piperazin-1-yl)-1,1-diphenyl-2-propanol) blocked increase in urethral pressure in female rats [127]. In frog, the activation of 5-HT2B receptors by $\alpha$-methey-5-HT (a 5-HT2B receptor agonist) facilitates $N$-methyl-D-aspartate (NMDA)-induced depolarization of motoneurons [128]. In addition, 5-HT2B receptors seemed to modulate respiratory activity in rats [123].

5-HT2C receptors: 5-HT2C receptor mRNAs and proteins were widely distributed in different laminae of the spinal gray matter including motoneurons as demonstrated by different 
experimental methods, such as PCR [105], autoradiography [68, 129], in situ hybridization [104, 107], and immunohistochemistry [36, 130-132]. Using PCR combined with Southern hybridization 5-HT2C receptor mRNAs were detected in spinal cord tissue from rat, monkey, and human, but not in cat spinal cord [105]. By using in situ hybridization, Fonseca et al. [107] showed that 5-HT2C receptor mRNAs were present at high levels in most parts of the spinal gray matter, except lamina II. Using immunohistochemistry, Ren et al. [36] have investigated 5-HT2C receptor expression in both normal and spinalized rats and the results showed that 5-HT2C receptors were widely distributed in different regions of the spinal gray matter (except lamina II) and were predominantly located in the neuronal somata and their dendrites although they also seemed to be present in axonal fibers in the superficial dorsal horn. Thus, the data from in situ hybridization and immunohistochemistry fit very well for this receptor subfamily.

The wide distribution of 5-HT2C receptors in different laminae of the spinal cord endows the receptors' role both in sensory information transmission and motor control. For the sensory information transmission available data point to that 5-HT2C receptors play roles both in pronociception [57, 112] and antinociception [96, 115, 133]. For their role on pronociception, refer to the part concerning 5-HT2A receptors since most studies used DOI (a common agonist for $5-\mathrm{HT} 2 \mathrm{~A}$ and $2 \mathrm{C}$ receptors) to stimulate and ketanserin to inhibit the receptors in response to different nociceptive stimulations. However, because ketanserin is mainly a 5-HT2A receptor antagonist some researchers argued that the pronociception effect should preferably attribute to 2-HT2A than $2 \mathrm{C}$ receptors. Their effects on antinociception seem to be adequately evidenced. For instance, in one study Jeong et al. [96] showed that in formalininduced pain model 5-HT2C receptor specific antagonist D-MC (N-ormethylclozapine/8chloro-11-(1-piperazinyl)-5H-dibenzo[b,e][1,4]diazepine) could block the suppression effect of 5-HT, whereas 5-HT2C receptor specific agonist MK-212 (6-chloro-2-(1-piperazinyl)pyrazine hydrochloride) could suppress the formalin response. In another study, Xie et al. [115] showed that a 5-HT2C receptor agonist WAY-161503 (8,9-dichloro-2,3,4,4a-tetrahydro-1H-pyrazino[1,2-a] quinoxalin-5(6H)) mimicked the 5-HT antinociceptive effect in dorsal horn neurons and this effect could be blocked by a 5-HT2C receptor antagonist, $N$-desmethylclozapine.

In motor control, one of the functions of 5-HT2C receptors is the induction of a long-lasting amplification of spinal reflex [73, 134-136]. Machacek et al. [134] showed that, in an in vitro neonatal rat spinal cord preparation, superfusion of 5-HT depressed reflex responses recorded in the ventral roots which was induced by electrical stimulation of primary afferents. However, following 5-HT washout, a long-lasting reflex facilitation was observed. Further pharmacological analysis indicated that it was the activation of 5-HT2C but not 5-HT2A receptors that was required for this long-lasting reflex. Although 5-HT2C receptors play a major role in long-term motor reflexes, they also play an inhibitory role in some physiological states. For example, in mice, when activated by DOI, 5-HT2C receptors inhibited the locomotor activity which opposed the effects of 5-HT2A receptors [137]. In addition, 5-HT2C receptors were also demonstrated to inhibit the micturition reflex $[119,127,138]$. Thus, Conlon et al. [138] showed that, in guinea pigs, Ro-600175 ( $(\alpha S)$-6-chloro-5-fluoro- $\alpha$-methyl- $1 H$ - 
indole-1-ethanamine fumarate), a 5-HT2C receptor agonist, increased peak urethral pressure in a dose-dependent manner. This effect was reversed by a selective 5-HT2C receptor antagonist SB-242084 (6-chloro-2,3-dihydro-5-methyl-N-[6-[(2-methyl-3-pyridinyl)oxy]-3pyridinyl]-1H-indole-1-carboxyamide) but not a 5 -HT2A or $2 \mathrm{~B}$ receptor antagonist. Similar results were also observed in rats $[119,127]$. Clinically, duloxetine, a serotonin-norepinephrine reuptake inhibitor, has been used to treat stress urinary incontinence. One possible mechanism for this effect may be the activation of 5-HT2C receptors in motoneurons in Onuf's nucleus, which leads to an increased activity of pudendal motor neurons and a subsequent increase in the strength of urethral sphincter contractions.

\section{3. $5-\mathrm{HT} 3$ receptors}

Although genes encoding the molecular structures of five different 5-HT3 receptor subfamilies (A-E) have been cloned, it is demonstrated so far that only the 5-HT3A subfamily is functional in homomeric form, and all other subfamilies require coassembling with 5-HT3A as functional heteromers $[62,139]$. Therefore, here $5-\mathrm{HT} 3$ receptors will be described together as one receptor unity. In the spinal cord, 5-HT3 receptors in the beginning were detected mainly in the dorsal horn with autoradiography and immunohistochemistry in rats and humans $[140,141]$. Later by using in situ hybridization and immunohistochemistry, they were found to be expressed in different laminae across the spinal gray matter [107, 142]. By using immunohistochemistry, Morales et al. [142] observed labeled cell bodies in the dorsal horn among the densely labeled fiber terminals. In the ventral horn, large neurons, likely motoneurons, were densely labeled. By using in situ hybridization, Fonseca et al. [107] found that 5-HT3 receptor mRNAs were expressed in different laminae in the rat spinal cord with very low levels in the dorsal horn, slightly higher levels in laminae VI through $\mathrm{X}$ and the highest level in lamina IX. Maxwell et al. [143] have studied the ultrastructure of 5-HT3 immunolabeled profiles in the dorsal horn of the rat spinal cord. They found that 5-HT3-immunopositive terminals invariably formed asymmetric synaptic junctions with dendritic profiles and often contained a mixture of granular and agranular vesicles. Immunoreactive cells were found to contain intense patches of reaction product within their cytoplasm. Although there are no data available regarding the subcellular morphology of 5-HT3 receptors in the ventral horn neurons, from the light microscopic data, it can be concluded that the receptor immunoreactive product was located at least in the cytoplasm [142].

It has long been known that 5-HT3 receptors modulate spinal nociceptive reflexes [144]. A large part of literature demonstrated a role of 5-HT3 receptors in antinociception in the spinal cord (e.g., $[145,146])$. This is likely due to, for instance, that the receptors interact with inhibitory interneurons such as GABA interneurons in the dorsal horn [147]. However, there are also data indicated that 5-HT3 receptors have a pronociceptive effect. For example, Guo et al. [148] showed that when the spinal 5-HT3 receptors were activated by intrathecal injection of a selective 5-HT3 receptor agonist SR-57227 (1-(6-chloropyridin-2-yl)piperidin-4-amine) spinal glial hyperactivity, neuronal hyperexcitability, and pain hypersensitivity were induced in rats. These diverse effects could be explained by, e.g., the expression of 5-HT3 
receptors in different neuronal components and/or the different effects of assemblies formed from different receptor subfamilies $[149,150]$.

Although 5-HT3 receptors are expressed in the ventral horn neurons data concerning their motor functions are scarce. A study by Guertin and Steuer [151] showed that in hindlimb paralyzed mice 5-HT3 receptor agonist SR-57227 could produce hindlimb movements although with a low score. This result indicates that 5-HT3 receptors might also modulate spinal motoneuron activity in normal states. In addition, the activation of 5-HT3 receptors by 2methyl-5-HT, another 5-HT3 receptor agonist, could induce sideward tail-flick reflex in rats [117], which might likely involve both sensory and motor components in the spinal cord. Further, 5-HT3 receptors have been reported to inhibit micturition in cats in both normal and spinalized situation [152].

\subsection{5-HT4 receptors}

Data concerning 5-HT4 receptors in the spinal cord are scarce. As far as I know, so far only one article reported the expression of 5-HT4 receptors in the spinal cord [153]. Using immunohistochemistry, Suwa et al. [153] investigated 5-HT4 receptor cell distribution in the brain and spinal cord in juvenile rats and found a high density of immunostained neurons in the ventral horn of the spinal cord. In addition, several sympathetic neurons were also seen to be immunopositive.

Similarly, studies about the functions of 5-HT4 receptors in the spinal cord are also rare. Using pharmacological method, Godínez-Chaparro et al. [154] showed that 5-HT in the spinal cord promotes the development and maintenance of secondary allodynia and hyperalgesia caused by formalin stimulation via the activation of 5-HT4/6/7 receptors. Considering the anatomical distribution of 5-HT4 receptors in the spinal cord, they should also play a role in some motor functions. Whether this is the case needs to be investigated further.

\subsection{5-HT5 receptors}

The 5-HT5 receptor family comprises two members: 5-HT5A and 5-HT5B. Although 5-HT5B receptors have been found in some structures in rat and mouse brain, they are not expressed in humans [155]. Therefore, I will only describe the 5-HT5A receptors in this chapter.

5-HT5A receptors were first identified in the rat spinal cord by Doly et al. [156]. They showed that in the rat spinal cord, 5-HT5A receptors were expressed with high density in the superficial dorsal horn (laminae I and II) especially in lamina II. In addition, they were also expressed in other regions including the intermediolateral nucleus in the thoracolumbar region and Onuf's nucleus in lumbosacral region. Ventral horn motoneurons in different regions were weakly labeled. Subcellularly, the receptors were found both in the cytoplasm and on the cell membrane of neuronal somata and dendrites. In the cytoplasm, they were associated with Golgi apparatus, rough endoplasmic reticulum, and vesicles. On the membrane, they were exclusively located on the postsynaptic density that was in clear contrast with the subcellular localization of 5-HT2A receptors [108, 110]. 
According to their locations in the spinal cord, it is speculated that 5-HT5A receptors are related to spinal modulation of pain, autonomic function, and control of micturition. Indeed, data from recent pharmacological studies have demonstrated that 5-HT-induced antinociceptive effect was mediated by spinal 5-HT5A receptors in several pain models, such as that induced by formalin, capsaicin, or acetic acid [58, 157]. For example, injection of 5-HT or 5-CT (an agonist of 5-HT5A receptors) could dose-dependently prevent nociception induced by formalin [157]. However, the speculated effects of the receptors on autonomic function and control of micturition yet need to be demonstrated.

\subsection{5-HT6 receptors}

Using RT-PCR, Gérard et al. [158] discovered the existence of 5-HT6 receptor mRNAs at a moderate level in the rat spinal cord. Later, using immunoautoradiogram, data from the same group showed that 5-HT6 receptor immunoreactive product seemed to be present across all laminae of the spinal gray matter with a denser labeling in the superficial dorsal horn and lamina IX [159]. No data are available about the subcellular distribution of 5-HT6 receptors in the spinal cord. However, according to the electron microscopic data from other brain regions such as the striatum and the hippocampus, 5-HT6 receptors were mainly associated with postsynaptic dendrites and no immunopositive axon terminals were found [159].

The exclusive roles of 5-HT6 receptors in the spinal cord yet remain to be elaborated. Using a formalin pain model in rats, Castañeda-Corral et al. [160] suggested that 5-HT6 receptors play a pronociceptive role in the spinal cord since intrathecal injection of EMD-386088 (5-chloro-2methyl-3-(1,2,3,6-tetrahydro-4-pyridinyl)- $1 \mathrm{H}$-indole), a selective 5-HT6 receptor agonist, enhanced formalin-induced nociception. It is unknown whether 5-HT6 receptors play any role in motor control.

\subsection{5-HT7 receptors}

As there were no specific radioligands for 5-HT7 receptors available, data concerning their distribution in the spinal cord acquired using autoradiography had been inconclusive [161] until 2005 when Doly et al. [162] used immunohistochemistry to study their distribution in the rat spinal cord. Doly et al. [162] showed that in the rat lumbar spinal cord 5-HT7 receptors were mainly located in two superficial laminae of the dorsal horn. Except in the Onuf's nucleus where the labeling was relatively denser, immunolabeling in the ventral horn motoneuron region was generally weak. At subcellular level, the receptors were found in the postsynaptic locations in neuronal cell bodies and dendrites as well as presynaptic locations in unmyelinated and thin myelinated axonal fibers. In addition, immunolabeling was also found in astrocytes. In cats, Noga et al. [16] found that in thoracolumbar spinal cord 5-HT7-immunolabeled cells spread across different laminae in the gray matter with a dorsoventral density gradient.

Available data showed that 5-HT7 receptors exert multiple roles in modulating both sensory and motor behavior. In sensory aspect 5-HT7 receptors have been demonstrated to exert dual but diverse actions in nociception depending on the different situations. In healthy rats, 5-HT7 
receptor agonists exerted a pronociceptive action but in neuropathic animals they exerted an antinociceptive action [163]. Yesilyurt et al. [164] showed that intrathecal application of SB-269970 ((2R)-1-[(3-hydroxyphenyl)sulfonyl]-2 -(2-(4-methyl-1-piperidinyl)ethyl)pyrrolidine), a 5-HT7 receptor antagonist, blocked both opioid and nonopioid type stress-induced analgesia, and this effect was mediated by descending serotonergic pathways and the spinal 5-HT7 receptors. Several pieces of evidence have indicated that the nonopioid analgesic drug Nefopam also took its effects via activation of 5-HT7 receptors [165, 166].

5-HT7 receptors have been demonstrated to be critical for 5-HT-induced locomotor-like activity [16, 167-169]. Liu and Jordan [167] showed that in rats 5-HT7 receptor antagonists blocked locomotor-like activity induced by stimulating mid-medulla region and also decreased step cycle duration. These results have been verified in 5-HT7 knockout mice [169]. Considering that 5-HT7 receptor antagonists blocked locomotor-like activity when applied only above the L3 segments [167], it is possible that they activated the central pattern generator neurons above this level that expressed 5-HT7 receptors and responded to 5-HT stimulation. Indeed, in decerebrated cats in which locomotion was induced by electrical stimulation of the mesencephalic locomotor region abundant c-Fos immunoreactive cells were observed in laminae VII and VIII throughout the thoracolumbar segments [16].

\section{Expression changes of different 5-HT receptors and their significance in motor outputs following SCI}

Following SCI the descending 5-HT projections are interrupted and as a consequence, a number of 5-HT receptors undergo different degrees of plastic changes below the lesion depending on the severity of injury, which on one hand will facilitate the re-establishment of neuronal circuits in the spinal cord below the lesion and thus promote functional recovery, and on the other hand will result in pathological symptoms. These changes can occur at both anatomical and functional levels. However, due to the fact that more functional than anatomical data are available, for some receptors only functional changes have been reported. So far 5-HT receptors that have been confirmed to undergo anatomical changes include, but are not limited to, 5-HT1 and 5-HT2 receptor families. In some other receptors, functional (activity) changes are indeed detected although there are no data revealing their anatomical changes. This group of receptors includes 5-HT3 and 5-HT7 receptors. So far there are no reports as to the anatomical or functional changes for 5-HT4, 5-HT5, and 5-HT6 receptors following SCI. Below I will mainly describe the 5-HT receptors that have been clearly demonstrated to undergo anatomical and/or functional changes in relation to their impact on motor outputs.

\subsection{5-HT1 receptors}

Among the different 5-HT1 subfamilies, 5-HT1A receptors were mostly investigated in terms of their anatomical and functional changes probably due to their direct involvement in functional recovery following SCI. For other subfamilies, such as 5-HT1B, 1D, and 1F, related 
studies were less abundant and results relating to their roles in motor functional outputs were also less conclusive.

5-HT1A receptors: Using autoradiography, the expression of 5-HT1A receptors have been shown to increase in the rat spinal cord 3 weeks following destruction of descending serotonergic fibers with 5,7-dihydroxytryptamine [83]. In cats, using the same technique, it was found that after spinal cord transection at T13 level binding density was significantly increased in laminae II, III, and X of lumbar segments at 15 and 30 days, but at 60 days the binding density recovered to the control level [28]. It should be addressed that using binding technique it is difficult to differentiate whether the labeled profiles were from neuronal cell bodies, their dendrites or axon fiber terminals. Using immunohistochemistry with two different 5HT1A antibodies, one labeling neuronal somata and the other labeling the axon initial segments, Otoshi et al. [31] reported that 8 weeks following complete spinal transection at T7T8 level the expression of 5-HT1A receptors in axon hillock was increased in laminae III, IV, VII, and IX, whereas the expression in neuronal somata and dendrites were increased in laminae VII and IX. This upregulation, both in the axon hillock and neuronal somata and dendrites, was dependent on the sensory input since the receptors were not upregulated when the spinal cord was isolated. Using in situ hybridization, Cornide-Petronio et al. [170] saw a similar upregulation time course for 5-HT1A receptors in lampreys as in cats. They reported an acute upregulation of 5-HT1A receptors in the spinal cord after SCI both in the rostral and caudal part of the lesion site, and the upregulation recovered to normal levels at 3 weeks. This quick recovery of 5-HT1A receptor expression may be due to that in lamprey serotonergic descending projecting neurons in the rhombencephalon could regenerate their axons across the lesion site after complete spinal cord transection [171]. Thus, the variation of results from these studies may partly reflect the different receptor responses to SCI in different species.

There is ample evidence that the activation of 5-HT1A receptors could induce motor functional recovery after SCI [13, 84, 172]. Antri et al. [13] found that, in thoracic spinal cord transected rats, after daily systemic application of 5-HT1A receptor agonist 8-OH-DPAT, locomotor function was significantly improved when compared with control spinalized animals. The agonist had both short- and long-term effects for motor functional improvement. A similar result was also demonstrated by Jackson and White [84] that in acute C1 spinal cord transected rats, after intravenous administration of 8-OH-DPAT, the excitability of spinal motoneurons was markedly enhanced. However, local application of 8-OH-DPAT directly into the ventral horn by microiontophoresis inhibited the glutamate-evoked firing of motoneurons. These results indicate that when 8-OH-DPAT was directly applied into the vicinity of the motoneurons it may activate 5-HT1A receptors in the axon hillock which inhibits the motoneuron firing [81]. However, the marked increase in firing of motoneurons induced by systemic administration of 8-OH-DPAT suggests that 5-HT1A receptors in other locations, likely at sites presynaptic to the motoneurons, have also been activated. In addition to the functions described above, 5-HT1A receptors have been reported to increase bladder capacity under saline or acid infused conditions in SCI cats [173].

5-HT1B receptors: In comparison with 5-HT1A receptors, studies concerning plastic changes of 5-HT1B receptors following SCI are sparse. Using autoradiography, Laporte et al. [83] 
reported that when descending serotonergic projections were destroyed by 5,7-dihydroxytryptamine the labeling of $5-\mathrm{HT} 1 \mathrm{~B}$ receptors was decreased $(-12 \%)$ in the dorsal horn at the cervical but not at the lumbar level in rats. Interestingly, when noradrenergic systems had been lesioned by DSP-4 (N-(2-chloroethyl)- $N$-ethyl-2-bromobenzylamine) there was an increase of labeling of 5-HT1B receptors both at the cervical level (+31\%) and the lumbar level (+17\%). In a C2 hemisection rat model, using quantitative RT-PCR, Mantilla et al. [86] did not detect expression changes of 5-HT1B receptors in phrenic motoneurons 2 or 3 weeks following the injury.

Similar to their functions in normal physiological states, in SCI states 5-HT1B receptors also play an inhibitory role for motor outputs possibly through inhibitions on both mono- and polysynaptic reflexes. In acute C1 spinalized rats, Honda et al. [174] showed that serotonergic depression of monosynaptic reflex transmission induced by application of 5-HTP was mediated by 5-HT1B receptors. In S2 spinal cord transection model (also called tail spasticity model), Murray et al. [99] showed that polysynaptic EPSPs that trigger muscle spasms after SCI were inhibited by 5 -HT1B receptors.

5-HT1D and 1F receptors: To my knowledge, no studies have investigated the expression changes of these two receptors following SCI. Functionally, the activation of 5-HT1D receptors seemed to reduce sensory transmission in both monosynaptic and polysynaptic reflexes in humans [95], and to inhibit bladder activity in cats after SCI [175]. The activation of 5-HT1F seemed to inhibit long polysynaptic reflexes in rats after SCI [99]. However because the agonists used in these studies were not specific enough for selected receptors the results were not conclusive.

\section{2. $5-\mathrm{HT} 2$ receptors}

5-HT2, especially 5-HT2A and 2C, receptors are the most intensely studied receptors among all 5-HT receptor families mostly due to their considerable effects on the motor functional recovery and perhaps also on the pathological symptoms developed following SCI such as spasticity. Due to the close relationship and similar functions of these three receptor subfamilies, their influences on the motor outputs after SCI will be described together.

5-HT2A receptors: Using different SCI animal models such as contusion, hemisection, and complete spinal transection, it is confirmed that 5-HT2A receptors underwent different degrees of plastic changes following SCI. In thoracic contusive rats using immunohistochemistry, Lee et al. [30] found a moderate yet significantly increased 5-HT2A receptor expression ( 1.2-fold of control) in the motoneurons at L5-L6 level after 4 weeks of injury. With the same method in a C2 hemisection rat model Fuller et al. [29] demonstrated a significant upregulation ( 1.7-fold of control) of 5-HT2A receptors in the ipsilateral phrenic motoneurons after 2 weeks of injury. In a S2 spinal transection model, Kong et al. [32, 33] reported a dramatic increase of 5-HT2A receptor immunoreactivity ( 5.6-fold of control) in the motoneurons below the lesion. The upregulation began as early as 1 day after injury, reached a maximal level by 28 days and lasted at least until 60 days, the longest time interval investigated. Similarly an upregulation of 5-HT2A receptors were also observed in chronic (6 weeks) thoracic spinal transected rats. Navarrett et al. [35] reported a $\sim 1.3$-fold increase of 5-HT2A 
receptor mRNAs in the spinal tissue (including both white and gray matter) below the lesion with RT-PCR. Upregulation of 5-HT2A receptor mRNAs was also reported in mice subjected to an acute thoracic spinal transection. Thus, Ung et al. [176] found that $3 \mathrm{~h}$ after the lesion 5HT2A receptor mRNA expression levels were increased 2.5-fold in the lateral intermediate zone in L1-L2 segments and they remained to be elevated for at least 2 weeks. However, no significant change was found in the ventral horn motoneuron regions, which was strikingly different from that in the rat.

5-HT2B receptors: No expression changes have been reported for this receptor subfamily in the spinal cord following SCI. With microarray global gene analysis technique, Wienecke et al. [122] did not detect significant changes of 5-HT2B receptor mRNAs in S2 spinal transected rats.

5-HT2C receptors: Similar to 5-HT2A receptors, 5-HT2C receptor expression changes have been investigated in different SCI animal models with different techniques. However, discrepancies exist as to whether 5-HT2C receptors are upregulated or not following SCI. In chronic SCI rats ( 15 weeks) severe contusion or transection at thoracic level (T9) could induce a significant increase of 5-HT2C receptor immunoreactivity in lumbar spinal cord [22]. The increase could reach 4-7-fold in the ventral horn and $~ 17$-fold in the dorsal horn over control level. In thoracic (T8-T9) spinal transected neonatal rats, following 4 weeks injury 5-HT2C receptor immunoreactivity was seen to increase $4-5$-fold both in the spinal dorsal and ventral horn [177]. In a S2 spinal transection rat model, data from our group [36] indicated that 5-HT2C receptor immunoreactivity increased in all parts of the spinal gray matter below the lesion from 2 weeks but did not reach a significant level until 3 weeks ( 1.4-fold over control animals). The increase sustained thereafter and a maximal level was reached at 45 days ( $\sim 1.7$-fold) and maintained at 60 days, the longest investigated interval. It is somehow perplexing that although upregulation was observed at protein level no significant increase at mRNA level was detected in different SCI animal models [34, 35, 122, 178]. However, although no significant changes of the total amount of 5-HT2C receptor mRNAs were detected, Murray et al. [34] did detect certain constitutive isoforms, such as INI isoform, that were significantly increased in the motoneurons 6 weeks after S2 spinal transection.

Functional significance for motor outputs of 5-HT2 receptors: The activation of 5-HT2 receptors has different effects on motor outputs after SCI, which include promoting motor functional recovery and causing maladaptive pathological motor symptoms such as spasticity. Due to uncertainty of the expression of 5-HT2B receptors in the spinal cord most studies have been focused on 5-HT2A and 2C receptors. There is ample evidence for the roles of 5-HT2A and $2 \mathrm{C}$ receptors in motor functional recovery following SCI from different studies (e.g., [9, 12, 14, $34,43,84,134,176,179,180]$, for reviews see [44, 45]). For example, in thoracic spinalized cats, when a 5 -HT2A/C receptor agonist (e.g., quipazine or DOI) was administrated $\alpha$-motoneuron excitability was increased and hindlimb motor activity was enhanced [9]. Similar results were also demonstrated in SCI rats [12,14] and mice [176]. Although 5-HT2A and 2C receptors both play a common role for motor functional recovery each subfamily may also exert different functions in different aspects of the motor outputs. Using different agonists and antagonists specific for each of these two receptor subfamilies it is found that 5-HT2A receptors might contribute to locomotor network activation and locomotor-like movement generation 
$[15,43,176]$. Direct stimulation of 5-HT2C receptors with its agonist meta-chlorophenylpiperazine improved weight-supported locomotion in adult rats spinalized as neonates [177, 181]. 5-HT2C, probably also $2 \mathrm{~B}$, but not 2A, receptors could become constitutively active which could contribute to motor functional recovery following SCI [34, 182].

One maladaptive consequence for 5-HT2 receptor plastic changes is the induction of muscle spasm due to increased motoneuron excitability. The rapid and robust upregulation of 5-HT2A receptors in spinal motoneurons might be responsible for 5-HT supersensitivity after SCI [32, 33]. Activation of 5-HT2C receptors could induce long-lasting reflexes of motoneurons in the in vitro spinal cord preparations [134, 135]. These long-lasting reflexes could be enhanced when 5-HT2C receptors became constitutively active following SCI $[34,182]$. One of the cellular mechanisms for the increased motoneuron excitability is that the activation of 5-HT2 receptors could enhance calcium and/or sodium persistent inward currents [42, 183].

In addition to promoting locomotion, 5-HT2 (especially 2A) receptors also play a significant role for respiratory functional recovery after cervical spinal hemisection [179] and in enhancing bladder function in thoracic spinal transected rats [184].

It should be addressed that the upregulation of 5-HT2 receptors does not by all means lead the motoneurons toward a hyperexcitatory state. Recently one interesting finding is presented by Bos et al. [185] who showed that the activation of 5-HT2A receptors could increase $\mathrm{K}(+)-$ $\mathrm{Cl}(-)$ cotransporter (KCC2) expression on cell membrane in the spinal cord motoneurons after SCI. The upregulation of KCC2 receptors in turn increased the activity of GABA A and glycine receptors which would restore endogenous inhibition and reduce spasticity after SCI in rats [186]. These results indicate that the upregulation of 5-HT2A receptors would not simply produce an excitatory effect. Rather, their activation will trigger an inhibitory factor which attempts to balance the excitatory effect. This effect seems to be paradoxical to the 5-HT2A receptors' direct excitatory effect on motoneurons. However, this might be one of the common functional mechanisms of a spinal network - different factors interact and compensate each other, and the final motor output is determined by a summed vector of these push-pull forces acted on the motoneurons. In fact, any motor action cannot be arisen solely from the activation of a single factor; instead it needs a concert activity of multiple factors including both excitatory and inhibitory. For instance, Hayashi et al. [22] have showed that in contusive SCI rats, application of 5-HT1A or 5-HT2C receptor agonists alone or in combination could not improve hindlimb motor function; rather, motor functional improvement could be achieved only when the 5-HT precursor 5-HTP was administrated, indicating that simultaneously multiple 5-HT receptor activations are needed for motor functional recovery. This concept is reinforced by the results from Noga et al. [16] who showed that in paralyzed, decerebrated cats, when locomotion was induced by electrical stimulation of the mesencephalic locomotor region, most locomotor-activated cells, labeled with c-Fos, colocalized with 5-HT1A, 5-HT2A, and 5-HT7 receptors in laminae VII and VIII in the thoracolumbar spinal region. 


\subsection{5-HT3 receptors}

There are no data demonstrating the expression changes of 5-HT3 following SCI. Laporte et al. [83] did not detect 5-HT3 receptor expression changes with binding technique in rat spinal cords whose descending serotonergic projections had been destroyed by 5,7-dihydroxytryptamine. However, lesions in peripheral nerves could reduce 5-HT3 receptor expression in the spinal motoneurons in rats [187].

Most studies concerning 5-HT3 receptor functions have been focused on sensory aspects, especially nociception. Studies relating to their functions in motor outputs after SCI are scarce. So far there is only one study having investigated the influence of the activation of 5-HT3 receptors on motor outputs in SCI mice. In this study, Guertin and Steuer [152] showed that in hindlimb paralyzed mice 5-HT3 receptor agonist SR-57227 could produce hindlimb movements although with a low score. This result, anyhow, provided the first evidence that 5-HT3 receptors could modulate spinal motoneuron activity after SCI.

\subsection{5-HT7 receptors}

So far there are no data available with respect to the expression changes of 5-HT7 receptors following SCI. However, the activation of 5-HT7 receptor has been shown to be related to locomotor functional recovery in SCI states [23, 43, 172]. Landry et al. [172] showed that in thoracic spinal transected mice systemic application of 8-OH-DPAT, an agonist for both 5HT1A and 5-HT7 receptors, acutely induced hindlimb movements with characteristics similar to normal locomotion. When the animals were pretreated with SB-269970, a selective 5-HT7 receptor antagonist, 8-OH-DPAT-induced movements were reduced. Sławińska et al. [23] showed that, in thoracic spinal transected rats, grafting of neurons from the B1, B2, and B3 descending 5-HT system from the brainstem into the spinal cord below the lesion effectively restored coordinated plantar stepping, and the application of SB-269970 disrupted the interand intralimb coordination. Further evidence from the same group indicated that 8-OH-DPAT facilitated plantar stepping in chronic spinalized rats [43]. Since 5-HT7 receptor agonists mainly improved coordination movement the authors assumed that 5-HT7 receptors mainly facilitated the activity of the central pattern generator interneurons. This assumption is supported by anatomical data that 5-HT7 receptors were mainly expressed in the neurons in the dorsal horn and the intermediate zone of the spinal gray matter [16]. In addition to the effects on locomotion, it has been reported that the activation of 5-HT7 receptors by their agonist LP44 (4-[2-(methylthio)phenyl]- $N$-(1,2,3,4-tetrahydronaphthalen-1-yl)-1-piperazinehexanamide) increased bladder voiding efficiency in chronic thoracic spinal transected rats [188].

\section{Plasticity of 5-HT innervations after SCI}

It is evidenced that a small number of 5-HT receptors, or more precisely receptor isoforms, could become active following SCI without ligand activation-so-called constitutive activation. However, for most of the 5-HT receptors that do not have constitutive isoforms the 
presence of their ligand-5HT is a necessity for their activation. Then, where could 5-HT originate following SCI? After contusion spinal cord injury or partial spinal cord transections there are still spared supraspinal serotonergic projections and these serotonergic fibers could undergo plastic changes to eventually supplement lost 5-HT supply in the injured spinal cord. For example, in contusion injury the density of spared 5-HT fibers below the lesion varies depending on the locations along the dorsoventral axis and the severity of the injury [22, 189, 190], and 5-HT innervation could be partially restored with time which is responsible at least partly for motor functional recovery [190]. In thoracic hemisection injury, the density of 5-HT fibers in the ipsilateral ventral horn varied from $8 \%$ to $30 \%$ of the control value according to studies with a postinjury interval 4-7 days [39, 191-194]. The data are inconsistent as to whether 5-HT fibers increase with time following hemisection. Some researchers reported a gradual increase of 5-HT fibers on the ipsilateral side below the lesion (e.g., [193, 195]), whereas some others did not see apparent changes (e.g., [39, 194]). For example, Saruhashi et al. [193] observed that 5-HT-immunoreactive fibers recovered from $20 \%$ to about $75 \%$ of the normal value in the ventral horn during first 4 weeks. Camand et al. [195] also reported a similar finding in the intermediate zone. However, Filli et al. [194] reported a decrease to about 10\% by 4 weeks from about $30 \%$ at day 4 in ventral horn motoneuron region. Azam et al. [39] reported that by 60 days the density of 5-HT-immunoreacitve fibers in the intermediate zone was reduced to $11 \%$ from $23 \%$ at 5 days, whereas in the ventral horn it was not reduced $(23 \%$ vs. $22 \%$ ). Following complete spinal transection, some $2-15 \%$ of the normal content of $5-\mathrm{HT}$ remained in the spinal cord below the lesion ([196]; for review see [25]).

The next question would be then where the residual 5-HT originates following complete spinal transection. One origin might be the intraspinal serotonergic neurons. However, intraspinal serotonergic neurons are very few in number and sparsely distributed (see Section 1). Then, what are the other possible sources? Recent findings from our [38] and Bennett's group [37] indicated that AADC cells in the spinal cord might be another origin. AADC is an essential enzyme for the synthesis of 5-HT, dopamine, and certain trace amines from their respective precursors. AADC cells are widely distributed in different regions of the spinal cord [38], not limiting to the area around the central canal as reported previously [197]. Following SCI the ability of AADC cells in the spinal cord to synthesize 5-HT/dopamine from 5-HTP/L-dopa was dramatically increased and 5-HT/dopamine produced in the AADC was responsible for the increased motoneuron ability recorded both in vivo and in vitro [37, 38, 40, 198]. Nonetheless, we have to admit that without 5-HTP application 5-HT could not be detected in the spinal AADC cells. This might be due to that the detecting techniques used in related studies were not sensitive enough to disclose a small amount of 5-HT, or the turnover rate of 5-HT produced in the AADC cells was so high that once produced it was immediately metabolized. One piece of evidence to support the speculation that monoamine transmitters could be produced from AADC cells in the spinal cord after SCI comes from Hou et al. [199], who showed that the number of dopamine-producing cells, which contained both AADC and tyrosine hydroxylase, was increased in lumbosacral spinal cord in thoracic spinal transected rats; and with enzyme-linked immunosorbent assay (ELISA) dopamine with a content of about $10 \%$ of its normal value could be detected in this part of the spinal cord even without L-dopa applica- 
tion. At the same time they also showed that dopamine produced from the spinal cord below the lesion was implicated for micturition functional recovery following SCI.

\section{Conclusions}

The serotonin system in the spinal cord is an important modulator for sensory, motor as well as autonomic function. This system normally exercises its function via the interaction between ligand 5-HT and a number of 5-HT receptors expressed in different structures in the spinal cord. Among the 145-HT receptor subfamilies at least 12 have been detected in the spinal cord, in which 5-HT1A, 2A, 2C, and 7 receptors have been demonstrated to be more important for motor control. In normal physiological states, these receptors coordinate with each other and also with other monoamine systems to enable smooth and controllable motor outputs for our physical activity [200]. Following SCI extensive plastic changes occur for a number of 5-HT receptor subfamilies, mostly with increased receptor numbers and/or constitutive activity. In addition, plasticity also occurs for descending serotonergic fibers (in the case of incomplete SCI) and intraspinal serotonin-producing cells. The coeffects of these plastic changes, together with the plastic changes of other monoamine systems, ultimately lead to increased motoneuron excitability in the chronic phase $[17,21,108]$. These plastic changes have both beneficial and detrimental effects for spinal motor outputs after SCI. Although the plastic changes can result in an adaptive compensation of the lost transmitters and thus assist in motor functional recovery, they can also result in a plethora of maladaptive problems, such as spasticity. In clinical practice, a strategy needs to be set so as to maximally take advantage of the positive side of the plasticity to promote motor functional recovery and meanwhile to reduce negative effects to a minimal extent. To reach this endpoint, pharmacological and/or genetic interferences need to be utilized so that the activity of different 5-HT receptors and 5-HT supply in the spinal cord reach a new balance and consequently an appropriate motor behavior is generated. Such a strategy would certainly have great implications for future treatment of SCI patients.

\section{Acknowledgements}

This work was supported by the Lundbeck Foundation and the Danish Medical Research Council.

\section{Abbreviations}

5-CT: 5-carboxamidotryptamine

5-HT: 5-hydroxytryptomine, serotonin

8-OH-DPAT: 8-hydroxy-2-(di- $n$-propylamino) tetralin

AADC: aromatic L-amino acid decarboxylase 
BRL-15572: 3-(4-(4-chlorophenyl)piperazin-1-yl)-1,1-diphenyl-2-propanol

C, T, L, and S: cervical, thoracic, lumbar, and sacral spinal cord, respectively

D-MC: N-ormethylclozapine/8-chloro-11-(1-piperazinyl)-5H-dibenzo[b,e][1,4]diazepine

DOI: ( \pm )-2,5-dimethoxy-4-iodoamphetamine hydrochloride

DOM: 2,5-dimethoxy-alpha,4-dimethyl-benzene ethamine hydrochloride

DSP-4: N-(2-chloroethyl)-N-ethyl-2-bromobenzylamine

ELISA: enzyme-linked immunosorbent assay

EMD-386088: 5-chloro-2-methyl-3-(1,2,3,6-tetrahydro-4-pyridinyl)-1H-indole

EPSP: excitatory postsynaptic potential

GABA: $\gamma$-aminobutyric acid

GR-46611: 3-[3-(2-dimethylaminoethyl)-1H-indol-5-yl]-N-(4-methoxybenzyl)acrylamide

$\mathrm{KCC} 2: \mathrm{K}(+)-\mathrm{Cl}(-)$ cotransporter

L-dopa: L-3,4-dihydroxyphenylalanine

LP44: $\quad$ 4-[2-(methylthio)phenyl]-N-(1,2,3,4-tetrahydronaphthalen-1-yl)-1-piperazinehexanamide

LY-344864: $\quad N$-[(3R)-3-(dimethylamino)-2,3,4,9-tetrahydro-1H-carbazol-6-yl]-4-fluorobenzamide

MK-212: 6-chloro-2-(1-piperazinyl)pyrazine hydrochloride

mRNA: messenger ribonucleic acid

NMDA: $N$-methyl-D-aspartate

PCR: polymerase chain reaction

Ro-600175: ( $\alpha S)$-6-chloro-5-fluoro- $\alpha$-methyl-1H-indole-1-ethanamine fumarate

RS-127445: (3-(4-(4-chlorophenyl)piperazin-1-yl)-1,1-diphenyl-2-propanol)

RT-PCT: reverse transcription polymerase chain reaction

RU-24969: 5-methoxy-3(1,2,3,6-tetrahydropyridin-4-yl)-1H-indole

SB-242084: 6-chloro-2,3-dihydro-5-methyl- $N$-[6-[(2-methyl-3-pyridinyl)oxy]-3-pyridinyl]- $1 H$ indole-1-carboxyamide

SB-269970: (2R)-1-[(3-hydroxyphenyl)sulfonyl]-2 -(2-(4-methyl-1-piperidinyl)ethyl)pyrrolidine

SCI: spinal cord injury

SR-57227: 1-(6-chloropyridin-2-yl)piperidin-4-amine 
TCB-2: 4-bromo-3,6-dimethoxybenzocyclobuten-1-yl)methylamine hydrobromide WAY-100635: N-[2-[4-(2-methoxyphenyl)-1-piperazinyl]ethyl]-N-(2-pyridyl)cyclohexanecarboxamide

WAY-161503: 8,9-dichloro-2,3,4,4a-tetrahydro-1H-pyrazino[1,2-a]quinoxalin-5(6H)

\section{Author details}

Mengliang Zhang ${ }^{1,2}$

Address all correspondence to: mzhang@sund.ku.dk

1 Department of Neuroscience and Pharmacology, University of Copenhagen, Copenhagen, Denmark

2 Neuronano Research Center, Department of Experimental Medical Science, Lund University, Lund, Sweden

\section{References}

[1] Witiw CD, Fehlings MG. Acute spinal cord injury. J Spinal Disord Tech. 2015;28:202210. DOI: 10.1097/BSD.0000000000000287.

[2] Jensen MP, Kuehn CM, Amtmann D, Cardenas DD. Symptom burden in persons with spinal cord injury. Arch Phys Med Rehabil. 2007;88:638-645. DOI: 10.1016/j.apmr. 2007.02.002.

[3] Nielsen JB, Crone C, Hultborn H. The spinal pathophysiology of spasticity-from a basic science point of view. Acta Physiol (Oxf). 2007;189:171-180. DOI: 10.1111/j. 1748-1716.2006.01652.x.

[4] Sheean G, McGuire JR. Spastic hypertonia and movement disorders: pathophysiology, clinical presentation, and quantification. PM R. 2009;1:827-833. DOI: 10.1016/j.pmrj. 2009.08.002.

[5] Gunduz H, Binak DF. Autonomic dysreflexia: an important cardiovascular complication in spinal cord injury patients. Cardiol J. 2012;19:215-219. DOI: 10.5603/CJ. 2012.0040.

[6] Felix ER. Chronic neuropathic pain in SCI: evaluation and treatment. Phys Med Rehabil Clin N Am. 2014;25:545-571. DOI: 10.1016/0006-8993(88)91548-X.

[7] Nas K, Yazmalar L, Şah V, Aydın A, Öneş K. Rehabilitation of spinal cord injuries. World J Orthop. 2015;6:8-16. DOI: 10.5312/wjo.v6.i1.8. 
[8] Guertin PA. New pharmacological approaches against chronic bowel and bladder problems in paralytics. World J Crit Care Med. 2016;5:1-6. DOI: 10.5492/wjccm.v5.i1.1.

[9] Barbeau H, Rossignol S. The effects of serotonergic drugs on the locomotor pattern and on cutaneous reflexes of the adult chronic spinal cat. Brain Res. 1990;514:55-67. DOI: 10.1016/0006-8993(90)90435-E.

[10] Kiehn O, Kjaerulff O. Spatiotemporal characteristics of 5-HT and dopamine-induced rhythmic hindlimb activity in the in vitro neonatal rat. J Neurophysiol. 1996;75:14721482.

[11] McEwen ML, Van Hartesveldt C, Stehouwer DJ. L-DOPA and quipazine elicit airstepping in neonatal rats with spinal cord transections. Behav Neurosci. 1997;111:825833. DOI: $10.1037 / 0735-7044.111 .4 .825$.

[12] Antri M, Orsal D, Barthe JY. Locomotor recovery in the chronic spinal rat: effects of long-term treatment with a 5-HT2 agonist. Eur J Neurosci. 2002;16:467-476. DOI: 10.1046/j.1460-9568.2002.02088.x.

[13] Antri M, Mouffle C, Orsal D, Barthe JY. 5-HT1A receptors are involved in short- and long-term processes responsible for 5-HT-induced locomotor function recovery in chronic spinal rat. Eur J Neurosci. 2003;18:1963-1972. DOI: 10.1046/j. 1460-9568.2003.02916.x.

[14] Antri M, Barthe JY, Mouffle C, Orsal D. Long-lasting recovery of locomotor function in chronic spinal rat following chronic combined pharmacological stimulation of serotonergic receptors with 8-OHDPAT and quipazine. Neurosci Lett. 2005;384:162267. DOI: 10.1016/j.neulet.2005.04.062.

[15] Landry ES, Guertin PA. Differential effects of 5-HT1 and 5-HT2 receptor agonists on hindlimb movements in paraplegic mice. Prog Neuropsychopharmacol Biol Psychiatry. 2004;28:1053-1060. DOI: 10.1016/j.pnpbp.2004.05.001.

[16] Noga BR, Johnson DM, Riesgo MI, Pinzon A. Locomotor-activated neurons of the cat. I. Serotonergic innervation and co-localization of 5-HT7, 5-HT2A, and 5-HT1A receptors in the thoraco-lumbar spinal cord. J Neurophysiol. 2009;102:1560-1576. DOI: 10.1152/jn.91179.2008.

[17] Musienko P, van den Brand R, Märzendorfer O, Roy RR, Gerasimenko Y, Edgerton VR, Courtine G. Controlling specific locomotor behaviors through multidimensional monoaminergic modulation of spinal circuitries. J Neurosci. 2011;31:9264-9278. DOI: 10.1523/JNEUROSCI.5796-10.2011.

[18] Feraboli-Lohnherr D, Orsal D, Yakovleff A, Giménez y Ribotta M, Privat A. Recovery of locomotor activity in the adult chronic spinal rat after sublesional transplantation of embryonic nervous cells: specific role of serotonergic neurons. Exp Brain Res. 1997;113:443-454. DOI: 10.1007/PL00005597.

[19] Orsal D, Barthe JY, Antri M, Feraboli-Lohnherr D, Yakovleff A, Giménez y Ribotta M, Privat A, Provencher J, Rossignol S. Locomotor recovery in chronic spinal rat: long- 
term pharmacological treatment or transplantation of embryonic neurons? Prog Brain Res. 2002;137:213-230.

[20] Kubasak MD, Jindrich DL, Zhong H, Takeoka A, McFarland KC, Muñoz-Quiles C, Roy RR, Edgerton VR, Ramón-Cueto A, Phelps PE. OEG implantation and step training enhance hindlimb-stepping ability in adult spinal transected rats. Brain. 2008;131:264276. DOI: 10.1093/brain/awm267.

[21] Courtine G, Gerasimenko Y, van den Brand R, Yew A, Musienko P, Zhong H, Song B, Ao Y, Ichiyama RM, Lavrov I, Roy RR, Sofroniew MV, Edgerton VR. Transformation of nonfunctional spinal circuits into functional states after the loss of brain input. Nat Neurosci. 2009;12:1333-1342. DOI: 10.1038/nn.2401.

[22] Hayashi Y, Jacob-Vadakot S, Dugan EA, McBride S, Olexa R, Simansky K, Murray M, Shumsky JS. 5-HT precursor loading, but not 5-HT receptor agonists, increases motor function after spinal cord contusion in adult rats. Exp Neurol. 2010;221:68-78. DOI: 10.1016/j.expneurol.2009.10.003.

[23] Sławińska U, Miazga K, Cabaj AM, Leszczyńska AN, Majczyński H, Nagy JI, Jordan LM. Grafting of fetal brainstem 5-HT neurons into the sublesional spinal cord of paraplegic rats restores coordinated hindlimb locomotion. Exp Neurol. 2013;247:572581. DOI: 10.1016/j.expneurol.2013.02.008.

[24] Jacobs BL, Fornal CA. Serotonin and motor activity. Curr Opin Neurobiol. 1997;7:820825. DOI: 10.1016/S0959-4388(97)80141-9.

[25] Schmidt BJ, Jordan LM. The role of serotonin in reflex modulation and locomotor rhythm production in the mammalian spinal cord. Brain Res Bull. 2000;53:689-710. DOI: 10.1016/S0361-9230(00)00402-0.

[26] Millan MJ. Descending control of pain. Prog Neurobiol. 2002;66:355-474. DOI: 10.1016/ S0301-0082(02)00009-6.

[27] Pearlstein E, Ben Mabrouk F, Pflieger JF, Vinay L. Serotonin refines the locomotorrelated alternations in the in vitro neonatal rat spinal cord. Eur J Neurosci. 2005;21:13381346. DOI: $10.1111 /$ j.1460-9568.2005.03971.x.

[28] Giroux N, Rossignol S, Reader TA. Autoradiographic study of alpha1- and alpha2noradrenergic and serotonin1A receptors in the spinal cord of normal and chronically transected cats. J Comp Neurol. 1999;406:402-414. DOI: 10.1002/ (SICI)1096-9861(19990412)406:3<402::AID-CNE8>3.0.CO;2-F.

[29] Fuller DD, Baker-Herman TL, Golder FJ, Doperalski NJ, Watters JJ, Mitchell GS. Cervical spinal cord injury upregulates ventral spinal 5-HT2A receptors. J Neurotrauma. 2005;22:203-213. DOI: 10.1089/neu.2005.22.203.

[30] Lee JK, Johnson CS, Wrathall JR. Up-regulation of 5-HT2 receptors is involved in the increased H-reflex amplitude after contusive spinal cord injury. Exp Neurol. 2007;203:502-511. DOI: 10.1016/j.expneurol.2006.09.003. 
[31] Otoshi CK, Walwyn WM, Tillakaratne NJ, Zhong H, Roy RR, Edgerton VR. Distribution and localization of 5-HT(1A) receptors in the rat lumbar spinal cord after transection and deafferentation. J Neurotrauma. 2009;26:575-584. DOI: 10.1089/neu.2008.0640.

[32] Kong X-Y, Wienecke J, Hultborn H, Zhang M. Robust upregulation of serotonin 2A receptors after chronic spinal transection of rats: an immunohistochemical study. Brain Res. 2010;1320:60-68. DOI: 10.1016/j.brainres.2010.01.030.

[33] Kong XY, Wienecke J, Chen M, Hultborn H, Zhang M. The time course of serotonin 2A receptor expression after spinal transection of rats: an immunohistochemical study. Neuroscience. 2011;177:114-126. DOI: 10.1016/j.neuroscience.2010.12.062.

[34] Murray KC, Nakae A, Stephens MJ, Rank M, D'Amico J, Harvey PJ, Li X, Harris RL, Ballou EW, Anelli R, Heckman CJ, Mashimo T, Vavrek R, Sanelli L, Gorassini MA, Bennett DJ, Fouad K. Recovery of motoneuron and locomotor function after spinal cord injury depends on constitutive activity in 5-HT2C receptors. Nat Med. 2010;16:694-700. DOI: $10.1038 / \mathrm{nm} .2160$.

[35] Navarrett S, Collier L, Cardozo C, Dracheva S. Alterations of serotonin 2C and 2A receptors in response to T10 spinal cord transection in rats. Neurosci Lett. 2012;506:7478. DOI: 10.1016/j.neulet.2011.10.052.

[36] Ren LQ, Wienecke J, Chen M, Møller M, Hultborn H, Zhang M. The time course of serotonin 2C receptor expression after spinal transection of rats: an immunohistochemical study. Neuroscience. 2013;236:31-46. DOI: 10.1016/j.neuroscience.2012.12.063.

[37] Li Y, Li L, Stephens MJ, Zenner D, Murray KC, Winship IR, Vavrek R, Baker GB, Fouad $\mathrm{K}$, Bennett DJ. Synthesis, transport, and metabolism of serotonin formed from exogenously applied 5-HTP after spinal cord injury in rats. J Neurophysiol. 2014;111:145163. DOI: 10.1152/jn.00508.2013.

[38] Wienecke J, Ren LQ, Hultborn H, Chen M, Møller M, Zhang Y, Zhang M. Spinal cord injury enables aromatic L-amino acid decarboxylase cells to synthesize monoamines. J Neurosci. 2014;34:11984-12000. DOI: 10.1523/JNEUROSCI.3838-13.2014.

[39] Azam B, Wienecke J, Jensen DB, Azam A, Zhang M. Spinal cord hemisection facilitates aromatic L-amino acid decarboxylase cells to produce serotonin in the subchronic but not the chronic phase. Neural Plast. 2015;2015:549671. DOI: 10.1155/2015/549671.

[40] Zhang M. Aromatic L-amino acid decarboxylase cells in the spinal cord: a potential origin of monoamines. Neural Regen Res. 2015;10:715-717. DOI: 10.4103/1673-5374.156960.

[41] Hains BC, Everhart AW, Fullwood SD, and Hulsebosch CE. Changes in serotonin, serotonin transporter expression and serotonin denervation supersensitivity: involvement in chronic central pain after spinal hemisection in the rat. Exp Neurol. 2002;175:347-362. DOI: 10.1006/exnr.2002.7892.

[42] Harvey PJ, Li X, Li Y, Bennett DJ. 5-HT2 receptor activation facilitates a persistent sodium current and repetitive firing in spinal motoneurons of rats with and without 
chronic spinal cord injury. J Neurophysiol. 2006;96:1158-1170. DOI: 10.1152/jn. 01088.2005.

[43] Sławińska U, Miazga K, Jordan LM. 5-HT2 and 5-HT7 receptor agonists facilitate plantar stepping in chronic spinal rats through actions on different populations of spinal neurons. Front Neural Circuits. 2014;8:95. DOI: 10.3389/fncir.2014.00095.

[44] Ghosh M, Pearse DD. The role of the serotonergic system in locomotor recovery after spinal cord injury. Front Neural Circuits. 2015;8:151. DOI: 10.3389/fncir.2014.00151.

[45] Nardone R, Höller Y, Thomschewski A, Höller P, Lochner P, Golaszewski S, Brigo F, Trinka E. Serotonergic transmission after spinal cord injury. J Neural Transm (Vienna). 2015;122:279-295. DOI: 10.1007/s00702-014-1241-z.

[46] Dahlstroem A, Fuxe K. Evidence for the existence of monoamine containing neurons in the central nervous system. I. Demonstration of monamines in the cell bodies of brain stem neurons. Acta Physiol Scand Suppl. 1964;62:1-55.

[47] Takeuchi Y, Kimura H, Sano Y. Immunohistochemical demonstration of serotonin neurons in the brainstem of the rat and cat. Cell Tissue Res. 1982;224:247-267. DOI: 10.1007/BF00216872.

[48] Skagerberg G, Björklund A. Topographic principles in the spinal projections of serotonergic and non-serotonergic brainstem neurons in the rat. Neuroscience. 1985;15:445-480. DOI: 10.1016/0306-4522(85)90225-8.

[49] Hornung JP. The human raphe nuclei and the serotonergic system. J Chem Neuroanat. 2003;26:331-343. DOI: 10.1016/j.jchemneu.2003.10.002.

[50] Azmitia EC, Gannon PJ. The primate serotonergic system: a review of human and animal studies and a report on macaca fasicularis. Adv Neurol. 1986;43:407-468.

[51] Ballion B, Branchereau P, Chapron J, Viala D. Ontogeny of descending serotonergic innervation and evidence for intraspinal 5-HT neurons in the mouse spinal cord. Brain Res Dev Brain Res. 2002;137:81-88. DOI: 10.1016/S0165-3806(02)00414-5.

[52] Jacobs BL, Azmitia EC. Structure and function of the brain serotonin system. Physiol Rev. 1992;72:165-229.

[53] Lamotte CC, Johns DR, de Lanerolle NC. Immunohistochemical evidence of indolamine neurons in monkey spinal cord. J Comp Neurol.1982; 206:359-570. DOI: 10.1002/ cne.902060404.

[54] Newton BW, Maley BE, Hamill RW. Immunohistochemical demonstration of serotonin neurons in autonomic regions of the rat spinal cord. Brain Res. 1986;376:155-163. DOI: 10.1016/0006-8993(86)90910-8.

[55] Newton BW, Hamill RW. The morphology and distribution of rat serotoninergic intraspinal neurons: an immunohistochemical study. Brain Res Bull. 1988;20:349-360. DOI: 10.1016/0361-9230(88)90064-0. 
[56] Jacobs BL, Fornal CA. 5-HT and motor control: a hypothesis. Trends Neurosci. 1993;16:346-352. DOI: 10.1016/0166-2236(93)90090-9.

[57] Rahman W, Bannister K, Bee LA, Dickenson AH. A pronociceptive role for the 5-HT2 receptor on spinal nociceptive transmission: an in vivo electrophysiological study in the rat. Brain Res. 2011;1382:29-36. DOI: 10.1016/j.brainres.2011.01.057.

[58] Cervantes-Durán C, Rocha-González HI, Granados-Soto V. Peripheral and spinal 5-HT receptors participate in the pronociceptive and antinociceptive effects of fluoxetine in rats. Neuroscience. 2013;252:396-409. DOI: 10.1016/j.neuroscience.2013.08.022.

[59] Beato M, Nistri A. Serotonin-induced inhibition of locomotor rhythm of the rat isolated spinal cord is mediated by the 5-HT1 receptor class. Proc Biol Sci. 1998;265:2073-2080. DOI: $10.1098 / \mathrm{rspb} .1998 .0542$.

[60] Perrier JF, Cotel F. Serotonin differentially modulates the intrinsic properties of spinal motoneurons from the adult turtle. J Physiol. 2008;586:1233-1238. DOI: 10.1113/ jphysiol.2007.145706.

[61] Nichols DE, Nichols CD. Serotonin receptors. Chem Rev. 2008;108:1614-1641. DOI: 10.1021/cr078224o.

[62] Hannon J, Hoyer D. Molecular biology of 5-HT receptors. Behav Brain Res. 2008;195:198-213. DOI: 10.1016/j.bbr.2008.03.020.

[63] Werry TD, Loiacono R, Sexton PM, Christopoulos A. RNA editing of the serotonin 5HT2C receptor and its effects on cell signalling, pharmacology and brain function. Pharmacol Ther. 2008;119:7-23. DOI: 10.1016/j.pharmthera.2008.03.012.

[64] Perrier JF, Rasmussen HB, Christensen RK, Petersen AV. Modulation of the intrinsic properties of motoneurons by serotonin. Curr Pharm Des. 2013;19:4371-4384. DOI: $10.2174 / 13816128113199990341$.

[65] Lanfumey L, Hamon M. 5-HT1 receptors. Curr Drug Targets CNS Neurol Disord. 2004;3:1-10. DOI: 10.2174/1568007043482570.

[66] Daval G, Vergé D, Basbaum AI, Bourgoin S, Hamon M. Autoradiographic evidence of serotonin1 binding sites on primary afferent fibres in the dorsal horn of the rat spinal cord. Neurosci Lett. 1987;83:71-76. DOI: 10.1016/0304-3940(87)90218-7.

[67] Marlier L, Teilhac JR, Cerruti C, Privat A. Autoradiographic mapping of 5-HT1, 5HT1A, 5-HT1B and 5-HT2 receptors in the rat spinal cord. Brain Res. 1991;550:15-23. DOI: 10.1016/0006-8993(91)90400-P.

[68] Thor KB, Nickolaus S, Helke CJ. Autoradiographic localization of 5-hydroxytryptamine1A, 5-hydroxytryptamine1B and 5-hydroxytryptamine1C/2 binding sites in the rat spinal cord. Neuroscience. 1993;55:235-252. DOI: 10.1016/0306-4522(93)90469-V.

[69] Kia HK, Miquel MC, Brisorgueil MJ, Daval G, Riad M, El Mestikawy S, Hamon M, Vergé D. Immunocytochemical localization of serotonin1A receptors in the rat central 
nervous system. J Comp Neurol. 1996;365:289-305. DOI: 10.1002/(SICI)1096-9861(19960205)365:2<289::AID-CNE7>3.0.CO;2-1.

[70] Talley EM, Bayliss DA. Postnatal development of 5-HT(1A) receptor expression in rat somatic motoneurons. Brain Res Dev Brain Res. 2000;122:1-10. DOI: 10.1016/ S0165-3806(00)00036-5.

[71] Kheck NM, Gannon PJ, Azmitia EC. 5-HT1A receptor localization on the axon hillock of cervical spinal motoneurons in primates. J Comp Neurol. 1995;355:211-220. DOI: 10.1002/cne.903550205.

[72] Eide PK, Joly NM, Hole K. The role of spinal cord 5-HT1A and 5-HT1B receptors in the modulation of a spinal nociceptive reflex. Brain Res. 1990;536:195-200. DOI: 10.1016/0006-8993(90)90025-7.

[73] Hochman S, Garraway SM, Machacek DW, Shay BL. 5-HT receptors and the neuromodulatory control of spinal cord function. In: Cope TC, editor. Motor Neurobiology of the Spinal Cord. CRC Press: Boca Raton; 2001. p. 47-87.

[74] Nadeson R, Goodchild CS. Antinociceptive role of 5-HT1A receptors in rat spinal cord. Br J Anaesth. 2002;88:679-684. DOI: 10.1093/bja/88.5.679.

[75] Buritova J, Larrue S, Aliaga M, Besson JM, Colpaert F. Effects of the high-efficacy 5HT1A receptor agonist, F 13640 in the formalin pain model: a c-Fos study. Eur J Pharmacol. 2005;514:121-130. DOI:10.1016/j.ejphar.2005.03.016.

[76] Kim JM, Jeong SW, Yang J, Lee SH, Kim WM, Jeong S, Bae HB, Yoon MH, Choi JI. Spinal 5-HT1A, not the 5-HT1B or 5-HT3 receptors, mediates descending serotonergic inhibition for late-phase mechanical allodynia of carrageenan-induced peripheral inflammation. Neurosci Lett. 2015;600:91-97. DOI: 10.1016/j.neulet.2015.05.058.

[77] Alhaider AA, Wilcox GL. Differential roles of 5-hydroxytryptamine1A and 5-hydroxytryptamine1B receptor subtypes in modulating spinal nociceptive transmission in mice. J Pharmacol Exp Ther. 1993;265:378-385.

[78] Ali Z, Wu G, Kozlov A, Barasi S. The actions of 5-HT1 agonists and antagonists on nociceptive processing in the rat spinal cord: results from behavioural and electrophysiological studies. Brain Res. 1994;661:83-90. DOI:10.1016/0006-8993(94)91184-3.

[79] Zhao ZQ, Liu XY, Jeffry J, Karunarathne WK, Li JL, Munanairi A, Zhou XY, Li H, Sun YG, Wan L, Wu ZY, Kim S, Huo FQ, Mo P, Barry DM, Zhang CK, Kim JY, Gautam N, Renner KJ, Li YQ, Chen ZF. Descending control of itch transmission by the serotonergic system via 5-HT1A-facilitated GRP-GRPR signaling. Neuron. 2014;84:821-834. DOI: 10.1016/j.neuron.2014.10.003.

[80] Bervoets K, Rivet JM, Millan MJ. 5-HT1A receptors and the tail-flick response. IV. Spinally localized 5-HT1A receptors postsynaptic to serotoninergic neurones mediate spontaneous tail-flicks in the rat. J Pharmacol Exp Ther. 1993;264:95-104. 
[81] Cotel F, Exley R, Cragg SJ, Perrier JF. Serotonin spillover onto the axon initial segment of motoneurons induces central fatigue by inhibiting action potential initiation. Proc Natl Acad Sci USA. 2013;110:4774-4779. DOI: 10.1073/pnas.1216150110.

[82] Perrier JF, Cotel F. Serotonergic modulation of spinal motor control. Curr Opin Neurobiol. 2015;33:1-7. DOI: 10.1016/j.conb.2014.12.008.

[83] Laporte AM, Fattaccini CM, Lombard MC, Chauveau J, Hamon M. Effects of dorsal rhizotomy and selective lesion of serotonergic and noradrenergic systems on 5-HT1A, 5-HT1B, and 5-HT3 receptors in the rat spinal cord. J Neural Transm Gen Sect. 1995;100:207-223. DOI: 10.1007/BF01276459.

[84] Jackson DA, White SR. Receptor subtypes mediating facilitation by serotonin of excitability of spinal motoneurons. Neuropharmacology.1990; 29:787-797. DOI: 10.1016/0028-3908(90)90151-G.

[85] Mantilla CB, Bailey JP, Zhan WZ, Sieck G. Phrenic motoneuron expression of serotonergic and glutamatergic receptors following upper cervical spinal cord injury. Exp Neurol. 2012;234:191-199. DOI: 10.1016/j.expneurol.2011.12.036.

[86] el-Yassir N, Fleetwood-Walker SM, Mitchell R. Heterogeneous effects of serotonin in the dorsal horn of rat: the involvement of 5-HT1 receptor subtypes. Brain Res. 1988;456:147-158. DOI: 10.1016/0006-8993(88)90356-3.

[87] Zhang Y, Yang Z, Gao X, Wu G. The role of 5-hydroxytryptamine1A and 5-hydroxytryptamine1B receptors in modulating spinalnociceptive transmission in normal and carrageenan-injected rats. Pain. 2001;92:201-211. DOI: 10.1016/S0304-3959(01)00259-7.

[88] Monroe PJ, Smith DJ. Demonstration of an autoreceptor modulating the release of $[3 \mathrm{H}] 5$-hydroxytryptamine from a synaptosomal-rich spinal cord tissue preparation. J Neurochem. 1985;45:1886-1894. DOI: 10.1111/j.1471-4159.1985.tb10548.x.

[89] Brown L, Amedro J, Williams G, Smith D. A pharmacological analysis of the rat spinal cord serotonin (5-HT) autoreceptor. Eur J Pharm. 1988;145: 163-171. DOI: 10.1016/0014-2999(88)90227-0.

[90] Murphy RM, Zemlan FP. Selective 5-HT1B agonists identify the 5-HT autoreceptor in lumbar spinal cord of rat. Neuropharmacology. 1988;27:37-42. DOI: 10.1016/0028-3908(88)90198-0.

[91] Allain AE, Ségu L, Meyrand P, Branchereau P. Serotonin controls the maturation of the GABA phenotype in the ventral spinal cord via 5-HT1b receptors. Ann N Y Acad Sci. 2010;1198:208-219. DOI: 10.1111/j.1749-6632.2010.05433.x.

[92] Potrebic S, Ahn AH, Skinner K, Fields HL, Basbaum AI. Peptidergic nociceptors of both trigeminal and dorsal root ganglia express serotonin 1D receptors: implications for the selective antimigraine action of triptans. J Neurosci. 2003;23:10988-10997. 
[93] Ahn AH, Basbaum AI. Tissue injury regulates serotonin 1D receptor expression: implications for the control of migraine and inflammatory pain. J Neurosci. 2006;26:8332-8338. DOI: 10.1523/JNEUROSCI.1989-06.2006.

[94] Enjin A, Leão KE, Mikulovic S, Le Merre P, Tourtellotte WG, Kullander K. Sensorimotor function is modulated by the serotonin receptor $1 \mathrm{~d}$, a novel marker for gamma motor neurons. Mol Cell Neurosci. 2012;49:322-332. DOI: 10.1016/j.mcn.2012.01.003.

[95] D'Amico JM, Li Y, Bennett DJ, Gorassini MA. Reduction of spinal sensory transmission by facilitation of 5-HT1B/D receptors in noninjured andspinal cord-injured humans. J Neurophysiol. 2013;109:1485-1493. DOI: 10.1152/jn.00822.2012.

[96] Jeong CY, Choi JI, Yoon MH. Roles of serotonin receptor subtypes for the antinociception of 5-HT in the spinal cord of rats. Eur J Pharmacol. 2004;502:205-211. DOI: 10.1016/ j.ejphar.2004.08.048.

[97] Honda M, Imaida K, Tanabe M, Ono H. Endogenously released 5-hydroxytryptamine depresses the spinal monosynaptic reflex via 5-HT1D receptors. Eur J Pharmacol. 2004;503:55-61. DOI: 10.1016/j.ejphar.2004.09.045.

[98] Castro ME, Pascual J, Romón T, del Arco C, del Olmo E, Pazos A. Differential distribution of $\left[{ }^{3} \mathrm{H}\right]$ sumatriptan binding sites (5-HT1B, 5-HT1D and 5-HT1F receptors) in human brain: focus on brainstem and spinal cord. Neuropharmacology. 1997;36:535542. DOI: 10.1016/S0028-3908(97)00061-0.

[99] Murray KC, Stephens MJ, Rank M, D'Amico J, Gorassini MA, Bennett DJ. Polysynaptic excitatory postsynaptic potentials that trigger spasms after spinal cord injury in rats are inhibited by 5-HT1B and 5-HT1F receptors. J Neurophysiol. 2011;106:925-943. DOI: 10.1152/jn.01011.2010.

[100] Classey JD, Bartsch T, Goadsby PJ. Distribution of 5-HT(1B), 5-HT(1D) and 5-HT(1F) receptor expression in rat trigeminal and dorsal root ganglia neurons: relevance to the selective anti-migraine effect of triptans. Brain Res. 2010;1361:76-85. DOI: 10.1016/ j.brainres.2010.09.004.

[101] Agosti RM. 5HT1F- and 5HT7-receptor agonists for the treatment of migraines. CNS Neurol Disord Drug Targets. 2007;6:235-237. DOI: 10.2174/187152707781387242.

[102] Ferrari MD, Färkkilä M, Reuter U, Pilgrim A, Davis C, Krauss M, Diener HC; European COL-144 Investigators. Acute treatment of migraine with the selective 5-HT1F receptor agonist lasmiditan-a randomised proof-of-concept trial. Cephalalgia. 2010;30:1170 1178. DOI: $10.1177 / 0333102410375512$.

[103] Humphrey PP, Hartig P, Hoyer D. A proposed new nomenclature for 5-HT receptors. Trends Pharmacol Sci. 1993;14:233-236. DOI: 10.1016/0165-6147(93)90016-D.

[104] Pompeiano M, Palacios JM, Mengod G. Distribution of the serotonin 5-HT2 receptor family mRNAs: comparison between 5-HT2A and 5-HT2C receptors. Brain Res Mol Brain Res. 1994;23:163-178. DOI: 10.1016/0169-328X(94)90223-2. 
[105] Helton LA, Thor KB, Baez M. 5-Hydroxytryptamine2A, 5-hydroxytryptamine2B, and 5-hydroxytryptamine2C receptor mRNA expression in the spinal cord of rat, cat, monkey and human. Neuroreport. 1994;5:2617-2620.

[106] Cornea-Hébert V, Riad M, Wu C, Singh SK, Descarries L. Cellular and subcellular distribution of the serotonin 5-HT2A receptor in the central nervous system of adult rat. J Comp Neurol. 1999;409:187-209. DOI: 10.1002/(SICI)1096-9861(19990628)409:2<187::AID-CNE2>3.0.CO;2-P.

[107] Fonseca MI, Ni YG, Dunning DD, Miledi R. Distribution of serotonin 2A, 2C and 3 receptor mRNA in spinal cord and medulla oblongata. Brain Res Mol Brain Res. 2001;89:11-19. DOI: 10.1016/S0169-328X(01)00049-3.

[108] Doly S, Madeira A, Fischer J, Brisorgueil MJ, Daval G, Bernard R, Verge D, Conrath M. The 5-HT2A receptor is widely distributed in the rat spinal cord and mainly localized at the plasma membrane of postsynaptic neurons. J Comp Neurol. 2004;472:496511. DOI: $10.1002 /$ cne.20082.

[109] Pineda-Farias JB, Velázquez-Lagunas I, Barragán-Iglesias P, Cervantes-Durán C, Granados-Soto V. 5- $\mathrm{HT}_{2 \mathrm{~B}}$ receptor antagonists reduce nerve injury-induced tactile allodynia and expression of 5- $\mathrm{HT}_{2 \mathrm{~B}}$ receptors. Drug Dev Res. 2015;76:31-39. DOI: 10.1002/ddr.21238.

[110] Xu C, Giuliano F, Sun XQ, Brisorgueil MJ, Leclerc P, Vergé D, Conrath M. Serotonin 5HT2A and 5-HT5A receptors are expressed by different motoneuron populations in rat Onuf's nucleus. J Comp Neurol. 2007;502:620-634. DOI: 10.1002/cne.21344.

[111] Eide PK, Hole K. Different role of 5-HT1A and 5-HT2 receptors in spinal cord in the control of nociceptive responsiveness. Neuropharmacology. 1991;30:727-731. DOI: 10.1016/0028-3908(91)90180-J.

[112] Kjørsvik A, Tjølsen A, Hole K. Activation of spinal serotonin(2A/2C) receptors augments nociceptive responses in the rat. Brain Res. 2001;910:179-181. DOI: 10.1016/ S0006-8993(01)02652-X.

[113] Nishiyama T. Effects of a 5-HT2A receptor antagonist, sarpogrelate on thermal or inflammatory pain. Eur J Pharmacol. 2005;516:18-22. DOI: 10.1016/j.ejphar.2005.04.026.

[114] Thibault K, Van Steenwinckel J, Brisorgueil MJ, Fischer J, Hamon M, Calvino B, Conrath M. Serotonin 5-HT2A receptor involvement and Fos expression at the spinal level in vincristine-induced neuropathy in the rat. Pain. 2008;140:305-322. DOI: 10.1016/j.pain. 2008.09.006.

[115] Xie DJ, Uta D, Feng PY, Wakita M, Shin MC, Furue H, Yoshimura M. Identification of 5-HT receptor subtypes enhancing inhibitory transmission in the rat spinal dorsal horn in vitro. Mol Pain. 2012;8:58. DOI: 10.1186/1744-8069-8-58.

[116] Iwasaki T, Otsuguro K, Kobayashi T, Ohta T, Ito S. Endogenously released 5-HT inhibits $\mathrm{A}$ and $\mathrm{C}$ fiber-evoked synaptic transmission in the rat spinal cord by the facilitation of 
GABA/glycine and 5-HT release via 5-HT(2A) and 5-HT(3) receptors. Eur J Pharmacol. 2013;702:149-157. DOI: 10.1016/j.ejphar.2013.01.058.

[117] Fone KC, Robinson AJ, Marsden CA. Characterization of the 5-HT receptor subtypes involved in the motor behaviours produced by intrathecal administration of 5-HT agonists in rats. $\mathrm{Br} \mathrm{J}$ Pharmacol. 1991;103:1547-1555. DOI: 10.1111/j. 1476-5381.1991.tb09825.x.

[118] Yamazaki J, Fukuda H, Nagao T, Ono H. 5-HT2/5-HT1C receptor-mediated facilitatory action on unit activity of ventral horn cells in rat spinal cord slices. Eur J Pharmacol. 1992;220:237-242. DOI: 10.1016/0014-2999(92)90753-Q.

[119] Mbaki Y, Gardiner J, McMurray G, Ramage AG. 5-HT 2A receptor activation of the external urethral sphincter and 5-HT $2 \mathrm{C}$ receptor inhibition of micturition: a study based on pharmacokinetics in the anaesthetized female rat. Eur J Pharmacol. 2012;682:142-152. DOI: 10.1016/j.ejphar.2012.02.010.

[120] Watson NV, Gorzalka BB. DOI-induced inhibition of copulatory behavior in male rats: reversal by 5-HT2 antagonists. Pharmacol Biochem Behav. 1991;39:605-612. DOI: 10.1016/0091-3057(91)90135-O.

[121] Rössler AS, Bernabé J, Denys P, Alexandre L, Giuliano F. Effect of the 5-HT receptor agonist DOI on female rat sexual behavior. J Sex Med. 2006;3:432-441. DOI: 10.1111/j. 1743-6109.2006.00240.x.

[122] Wienecke J, Westerdahl AC, Hultborn H, Kiehn O, Ryge J. Global gene expression analysis of rodent motor neurons following spinal cord injury associates molecular mechanisms with development of postinjury spasticity. J Neurophysiol. 2010;103:761778. DOI: 10.1152/jn.00609.2009.

[123] MacFarlane PM, Vinit S, Mitchell GS. Serotonin 2A and 2B receptor-induced phrenic motor facilitation: differential requirement for spinal NADPH oxidase activity. Neuroscience. 2011;178:45-55. DOI: 10.1016/j.neuroscience.2011.01.011.

[124] Lin SY, Chang WJ, Lin CS, Huang CY, Wang HF, Sun WH. Serotonin receptor 5-HT2B mediates serotonin-induced mechanical hyperalgesia. J Neurosci. 2011;31:1410-1418. DOI: 10.1523/JNEUROSCI.4682-10.2011.

[125] Aira Z, Buesa I, García del Caño G, Salgueiro M, Mendiable N, Mingo J, Aguilera L, Bilbao J, Azkue JJ. Selective impairment of spinal mu-opioid receptor mechanism by plasticity of serotonergic facilitation mediated by 5-HT2A and 5-HT2B receptors. Pain. 2012;153:1418-1425. DOI: 10.1016/j.pain.2012.03.017.

[126] Cervantes-Durán C, Vidal-Cantú GC, Barragán-Iglesias P, Pineda-Farias JB, BravoHernández M, Murbartián J, Granados-Soto V. Role of peripheral and spinal 5-HT2B receptors in formalin-induced nociception. Pharmacol Biochem Behav. 2012;102:30-35. DOI: 10.1016/j.pbb.2012.03.015. 
[127] Mbaki Y, Ramage AG. Investigation of the role of 5-HT2 receptor subtypes in the control of the bladder and the urethra in the anaesthetized female rat. Br J Pharmacol. 2008;155:343-356. DOI: 10.1038/bjp.2008.273.

[128] Holohean AM, Hackman JC. Mechanisms intrinsic to 5-HT2B receptor-induced potentiation of NMDA receptor responses in frog motoneurones. Br J Pharmacol. 2004;143:351-360. DOI: 10.1038/sj.bjp.0705935.

[129] Pranzatelli MR, Murthy JN, Pluchino RS. Identification of spinal 5-HT1C binding sites in the rat: characterization of $\left[{ }^{3} \mathrm{H}\right]$ mesulergine binding. J Pharmacol Exp Ther. 1992;261:161-165.

[130] Bancila M, Vergé D, Rampin O, Backstrom JR, Sanders-Bush E, McKenna KE, Marson L, Calas A, Giuliano F. 5-Hydroxytryptamine 2C receptors on spinal neurons controlling penile erection in the rat. Neuroscience. 1999;92:1523-1537. DOI: 10.1016/ S0306-4522(99)00082-2.

[131] Clemett DA, Punhani T, Duxon MS, Blackburn TP, Fone KC. Immunohistochemical localisation of the 5-HT2C receptor protein in the rat CNS. Neuropharmacology. 2000;39:123-132. DOI: 10.1016/S0028-3908(99)00086-6.

[132] Holmes GM. 5-Hydroxytryptamine2C receptors on pudendal motoneurons innervating the external anal sphincter. Brain Res. 2005;1057:65-71. DOI: 10.1016/j.brainres. 2005.07.047.

[133] Obata H, Saito S, Sakurazawa S, Sasaki M, Usui T, Goto F. Antiallodynic effects of intrathecally administered 5-HT(2C) receptor agonists in rats with nerve injury. Pain. 2004;108:163-169. DOI: 10.1016/j.pain.2003.12.019.

[134] Machacek DW, Garraway SM, Shay BL, Hochman S. Serotonin 5-HT(2) receptor activation induces a long-lasting amplification of spinal reflex actions in the rat. J Physiol. 2001;537:201-207. DOI: 10.1111/j.1469-7793.2001.0201k.x.

[135] Shay BL, Sawchuk M, Machacek DW, Hochman S. Serotonin 5-HT2 receptors induce a long-lasting facilitation of spinal reflexes independent of ionotropic receptor activity. J Neurophysiol. 2005;94:2867-2877. DOI: 10.1152/jn.00465.2005.

[136] Gajendiran M. In vivo evidence for serotonin 5-HT2C receptor-mediated long-lasting excitability of lumbar spinal reflex and its functional interaction with 5-HT1A receptor in the mammalian spinal cord. Brain Res Bull. 2008;75:674-680. DOI: 10.1016/ j.brainresbull.2007.11.003.

[137] Halberstadt AL, van der Heijden I, Ruderman MA, Risbrough VB, Gingrich JA, Geyer MA, Powell SB. 5-HT(2A) and 5-HT(2C) receptors exert opposing effects on locomotor activity in mice. Neuropsychopharmacology. 2009;34:1958-1967. DOI: 10.1038/ npp.2009.29. 
[138] Conlon K, Miner W, McCleary S, McMurray G. Identification of 5-HT(2C) mediated mechanisms involved in urethral sphincter reflexes in a guinea-pig model of urethral function. BJU Int. 2012;110:E113-117. DOI: 10.1111/j.1464-410X.2011.10756.x.

[139] Thompson AJ, Lummis SC. Discriminating between 5- $\mathrm{HT}_{3} \mathrm{~A}$ and 5- $\mathrm{HT}_{3} \mathrm{AB}$ receptors. Br J Pharmacol. 2013;169:736-747. DOI: 10.1111/bph.12166.

[140] Kia HK, Miquel MC, McKernan RM, Laporte AM, Lombard MC, Bourgoin S, Hamon M, Vergé D. Localization of 5-HT3 receptors in the rat spinal cord: immunohistochemistry and in situ hybridization. Neuroreport. 1995;6:257-261.

[141] Laporte AM, Doyen C, Nevo IT, Chauveau J, Hauw JJ, Hamon M. Autoradiographic mapping of serotonin 5-HT1A, 5-HT1D, 5-HT2A and 5-HT3 receptors in the aged human spinal cord. J Chem Neuroanat. 1996;11:67-75. DOI: 10.1016/0891-0618(96)00130-5.

[142] Morales M, Battenberg E, Bloom FE. Distribution of neurons expressing immunoreactivity for the $5 \mathrm{HT} 3$ receptor subtype in the rat brain and spinal cord. J Comp Neurol. 1998;402:385-401. DOI: 10.1002/(SICI)1096-9861(19981221)402:3<385::AIDCNE7>3.0.CO;2-Q.

[143] Maxwell DJ, Kerr R, Rashid S, Anderson E. Characterisation of axon terminals in the rat dorsal horn that are immunoreactive for serotonin 5-HT3A receptor subunits. Exp Brain Res. 2003;149:114-124. DOI: 10.1007/s00221-002-1339-7.

[144] Glaum SR, Proudfit HK, Anderson EG. 5-HT3 receptors modulate spinal nociceptive reflexes. Brain Res. 1990;510:12-16. DOI: 10.1016/0006-8993(90)90721-M.

[145] Alhaider AA, Lei SZ, Wilcox GL. Spinal 5-HT3 receptor-mediated antinociception: possible release of GABA. J Neurosci. 1991;11:1881-1888.

[146] Khasabov SG, Lopez-Garcia JA, Asghar AU, King AE. Modulation of afferent-evoked neurotransmission by 5 -HT3 receptors in young rat dorsal horn neurones in vitro: a putative mechanism of 5-HT3 induced anti-nociception. Br J Pharmacol. 1999;127:843852. DOI: $10.1038 /$ sj.bjp.0702592.

[147] Fukushima T, Ohtsubo T, Tsuda M, Yanagawa Y, Hori Y. Facilitatory actions of serotonin type 3 receptors on GABAergic inhibitory synaptic transmission in the spinal superficial dorsal horn. J Neurophysiol. 2009;102:1459-1471. DOI: 10.1152/jn. 91160.2008.

[148] Guo W, Miyoshi K, Dubner R, Gu M, Li M, Liu J, Yang J, Zou S, Ren K, Noguchi K, Wei F. Spinal 5-HT3 receptors mediate descending facilitation and contribute to behavioral hypersensitivity via a reciprocal neuron-glial signaling cascade. Mol Pain. 2014;10:35. DOI: 10.1186/1744-8069-10-35.

[149] Conte D, Legg ED, McCourt AC, Silajdzic E, Nagy GG, Maxwell DJ. Transmitter content, origins and connections of axons in the spinal cord that possess theserotonin 
(5-hydroxytryptamine) 3 receptor. Neuroscience. 2005;134:165-173. DOI: 10.1016/ j.neuroscience.2005.02.013.

[150] Huang J, Wang YY, Wang W, Li YQ, Tamamaki N, Wu SX. 5-HT(3A) receptor subunit is expressed in a subpopulation of GABAergic and enkephalinergic neurons in the mouse dorsal spinal cord. Neurosci Lett. 2008;441:1-6. DOI: 10.1016/j.neulet. 2008.04.105.

[151] Guertin PA, Steuer I. Ionotropic 5-HT3 receptor agonist-induced motor responses in the hindlimbs of paraplegic mice. J Neurophysiol. 2005;94:3397-3405. DOI: 10.1152/jn. 00587.2005.

[152] Espey MJ, Downie JW. Serotonergic modulation of cat bladder function before and after spinal transection. Eur J Pharmacol. 1995;287:173-177. DOI: 10.1016/0014-2999(95)00614-1.

[153] Suwa B, Bock N, Preusse S, Rothenberger A, Manzke T. Distribution of serotonin4(a) receptors in the juvenile rat brain and spinal cord. J Chem Neuroanat. 2014;55:67-77. DOI: 10.1016/j.jchemneu.2013.12.004.

[154] Godínez-Chaparro B, López-Santillán FJ, Orduña P, Granados-Soto V. Secondary mechanical allodynia and hyperalgesia depend on descending facilitation mediated byspinal 5-HT4, 5-HT6 and 5-HT7 receptors. Neuroscience. 2012;222:379-391. DOI: 10.1016/j.neuroscience.2012.07.008.

[155] Grailhe R, Grabtree GW, Hen R. Human 5-HT(5) receptors: the 5-HT(5A) receptor is functional but the $5-\mathrm{HT}(5 \mathrm{~B})$ receptor was lost during mammalian evolution. Eur J Pharmacol. 2001;418:157-167. DOI: 10.1016/S0014-2999(01)00933-5.

[156] Doly S, Fischer J, Brisorgueil MJ, Vergé D, Conrath M. 5-HT5A receptor localization in the rat spinal cord suggests a role in nociception and control of pelvic floor musculature. J Comp Neurol. 2004;476:316-329. DOI: 10.1002/cne.20214.

[157] Muñoz-Islas E, Vidal-Cantú GC, Bravo-Hernández M, Cervantes-Durán C, QuiñonezBastidas GN, Pineda-Farias JB, Barragán-Iglesias P, Granados-Soto V. Spinal 5-HT5A receptors mediate 5-HT-induced antinociception in several pain models in rats. Pharmacol Biochem Behav. 2014;120:25-32. DOI: 10.1016/j.pbb.2014.02.001.

[158] Gérard C, el Mestikawy S, Lebrand C, Adrien J, Ruat M, Traiffort E, Hamon M, Martres MP. Quantitative RT-PCR distribution of serotonin 5-HT6 receptor mRNA in the central nervous system of control or 5,7-dihydroxytryptamine-treated rats. Synapse. 1996;23:164-173. DOI: 10.1002/(SICI)1098-2396(199607)23:3<164::AID-SYN5>3.0.CO; $2-6$.

[159] Gérard C, Martres MP, Lefèvre K, Miquel MC, Vergé D, Lanfumey L, Doucet E, Hamon M, el Mestikawy S. Immuno-localization of serotonin 5-HT6 receptor-like material in the rat central nervous system. Brain Res. 1997;746:207-219. DOI: 10.1016/ S0006-8993(96)01224-3. 
[160] Castañeda-Corral G, Rocha-González HI, Araiza-Saldaña CI, Ambriz-Tututi M, VidalCantú GC, Granados-Soto V. Role of peripheral and spinal 5-HT6 receptors according to the rat formalin test. Neuroscience. 2009;162:444-452. DOI: 10.1016/ j.neuroscience.2009.04.072.

[161] To ZP, Bonhaus DW, Eglen RM, Jakeman LB. Characterization and distribution of putative 5-ht7 receptors in guinea-pig brain. Br J Pharmacol. 1995;115:107-116. DOI: 10.1111/j.1476-5381.1995.tb16327.x.

[162] Doly S, Fischer J, Brisorgueil MJ, Vergé D, Conrath M. Pre- and postsynaptic localization of the 5-HT7 receptor in rat dorsal spinal cord: immunocytochemical evidence. J Comp Neurol. 2005;490:256-269. DOI: 10.1002/cne.20667.

[163] Viguier F, Michot B, Hamon M, Bourgoin S. Multiple roles of serotonin in pain control mechanisms - implications of 5-HT7 and other 5-HT receptor types. Eur J Pharmacol. 2013;716:8-16. DOI: 10.1016/j.ejphar.2013.01.074.

[164] Yesilyurt O, Seyrek M, Tasdemir S, Kahraman S, Deveci MS, Karakus E, Halici Z, Dogrul A. The critical role of spinal 5-HT7 receptors in opioid and non-opioid type stress-induced analgesia. Eur J Pharmacol. 2015;762:402-410. DOI: 10.1016/j.ejphar. 2015.04.020.

[165] Dam LJ, Hai L, Ha YM. Role of the 5-HT(7) receptor in the effects of intrathecal nefopam in neuropathic pain in rats. Neurosci Lett. 2014;566:50-54. DOI: 10.1016/j.neulet. 2014.02.021.

[166] Lee HG, Kim WM, Kim JM, Bae HB, Choi JI. Intrathecal nefopam-induced antinociception through activation of descending serotonergic projections involving spinal 5HT7 but not 5-HT3 receptors. Neurosci Lett. 2015;587:120-125. DOI: 10.1016/j.neulet. 2014.12.040.

[167] Liu J, Jordan LM. Stimulation of the parapyramidal region of the neonatal rat brain stem produces locomotor-like activity involving spinal 5-HT7 and 5-HT2A receptors. J Neurophysiol. 2005;94:1392-1404. DOI: 10.1152/jn.00136.2005.

[168] Jordan LM, Liu J, Hedlund PB, Akay T, Pearson KG. Descending command systems for the initiation of locomotion in mammals. Brain Res Rev. 2008;57:183-191. DOI: 10.1016/j.brainresrev.2007.07.019.

[169] Liu J, Akay T, Hedlund PB, Pearson KG, Jordan LM. Spinal 5-HT7 receptors are critical for alternating activity during locomotion: in vitro neonatal and in vivo adult studies using 5-HT7 receptor knockout mice. J Neurophysiol. 2009;102:337-348. DOI: 10.1152/ jn.91239.2008.

[170] Cornide-Petronio ME, Fernández-López B, Barreiro-Iglesias A, Rodicio MC. Traumatic injury induces changes in the expression of the serotonin 1A receptor in the spinal cord of lampreys. Neuropharmacology. 2014;77:369-378. DOI: 10.1016/j.neuropharm. 2013.10.017. 
[171] Cornide-Petronio ME, Ruiz MS, Barreiro-Iglesias A, Rodicio MC. Spontaneous regeneration of the serotonergic descending innervation in the sea lamprey after spinal cord injury. J Neurotrauma. 2011;28:2535-2540. DOI: 10.1089/neu.2011.1766.

[172] Landry ES, Lapointe NP, Rouillard C, Levesque D, Hedlund PB, Guertin PA. Contribution of spinal 5-HT1A and 5-HT7 receptors to locomotor-like movement induced by 8-OH-DPAT in spinal cord-transected mice. Eur J Neurosci. 2006;24:535546. DOI: 10.1111/j.1460-9568.2006.04917.x.

[173] Gu B, Thor KB, Reiter JP, Dolber PC. Effect of 5-hydroxytryptamine1 serotonin receptor agonists on noxiously stimulated micturition in cats with chronic spinal cord injury. J Urol. 2007;177:2381-2385. DOI: 10.1016/j.juro.2007.01.110.

[174] Honda M, Tanabe M, Ono H. Serotonergic depression of spinal monosynaptic transmission is mediated by 5-HT1B receptors. Eur J Pharmacol. 2003;482:155-161. DOI: 10.1016/j.ejphar.2003.09.070.

[175] Gu B, Olejar KJ, Reiter JP, Thor KB, Dolber PC. Inhibition of bladder activity by 5hydroxytryptamine1 serotonin receptor agonists in cats with chronicspinal cord injury. J Pharmacol Exp Ther. 2004;310:1266-1272. DOI: 10.1124/jpet.103.063842.

[176] Ung RV, Landry ES, Rouleau P, Lapointe NP, Rouillard C, Guertin PA. Role of spinal 5-HT2 receptor subtypes in quipazine-induced hindlimb movements after a lowthoracic spinal cord transection. Eur J Neurosci. 2008;28:2231-2242. DOI: 10.1111/j. 1460-9568.2008.06508.x.

[177] Kao T, Shumsky JS, Jacob-Vadakot S, Himes BT, Murray M, Moxon K. Role of the 5HT2C receptor in improving weight-supported stepping in adult rats spinalized as neonates. Brain Res. 2006;1112:159-168. DOI: 10.1016/j.brainres.2006.07.020.

[178] Basura GJ, Zhou SY, Walker PD, Goshgarian HG. Distribution of serotonin 2A and $2 \mathrm{C}$ receptor mRNA expression in the cervical ventral horn and phrenic motoneurons following spinal cord hemisection. Exp Neurol. 2001;169:255-263. DOI: 10.1006/exnr. 2001.7682.

[179] Zhou SY, Basura GJ, Goshgarian HG. Serotonin (2) receptors mediate respiratory recovery after cervical spinal cord hemisection in adult rats. J Appl Physiol. 2001;91:2665-2673.

[180] Majczyński H, Maleszak K, Cabaj A, Sławińska U. Serotonin-related enhancement of recovery of hind limb motor functions in spinal rats after grafting of embryonic raphe nuclei. J Neurotrauma. 2005;22:590-604. DOI: 10.1089/neu.2005.22.590.

[181] Kim D, Murray M, Simansky KJ. The serotonergic 5-HT(2C) agonist m-chlorophenylpiperazine increases weight-supported locomotion without development of tolerance in rats with spinal transections. Exp Neurol. 2001;169:496-500. DOI: 10.1006/ exnr.2001.7660. 
[182] Murray KC, Stephens MJ, Ballou EW, Heckman CJ, Bennett DJ. Motoneuron excitability and muscle spasms are regulated by 5-HT2B and 5-HT2C receptor activity. J Neurophysiol. 2011;105:731-748. DOI: 10.1152/jn.00774.2010.

[183] Perrier JF, Hounsgaard J. 5-HT2 receptors promote plateau potentials in turtle spinal motoneurons by facilitating an L-type calcium current. J Neurophysiol. 2003;89:954959. DOI: 10.1152/jn.00753.2002.

[184] Chen J, Gu B, Wu G, Tu H, Si J, Xu Y, Andersson KE. The effect of the 5-HT2A/2C receptor agonist DOI on micturition in rats with chronic spinal cord injury. J Urol. 2013;189:1982-1988. DOI: 10.1016/j.juro.2012.11.049.

[185] Bos R, Sadlaoud K, Boulenguez P, Buttigieg D, Liabeuf S, Brocard C, Haase G, Bras H, Vinay L. Activation of 5-HT2A receptors upregulates the function of the neuronal KCl cotransporter KCC2. Proc Natl Acad Sci USA. 2013;110:348-353. DOI: 10.1073/ pnas.1213680110.

[186] Gackière F, Vinay L. Serotonergic modulation of post-synaptic inhibition and locomotor alternating pattern in the spinal cord. Front Neural Circuits. 2014;8:102. DOI: 10.3389/fncir.2014.00102.

[187] Rende M, Morales M, Brizi E, Bruno R, Bloom F, Sanna PP. Modulation of serotonin 5HT3 receptor expression in injured adult rat spinal cord motoneurons. Brain Res. 1999;823:234-240. DOI: 10.1016/S0006-8993(99)01180-4.

[188] Gang W, Hongjian T, Jasheng C, Jiemin S, Zhong C, Yuemin X, Baojun G, Andersson KE. The effect of the 5-HT7 serotonin receptor agonist, LP44, on micturition in rats with chronic spinal cord injury. Neurourol Urodyn. 2014;33:1165-1170. DOI: 10.1002/nau. 22463.

[189] Faden AI, Gannon A, Basbaum AI. Use of serotonin immunocytochemistry as a marker of injury severity after experimental spinal trauma in rats. Brain Res. 1988;450:94-100. DOI: 10.1016/0006-8993(88)91548-X.

[190] Holmes GM, Van Meter MJ, Beattie MS, Bresnahan JC. Serotonergic fiber sprouting to external anal sphincter motoneurons after spinal cord contusion. Exp Neurol. 2005;193:29-42. DOI: 10.1016/j.expneurol.2005.01.002.

[191] Hadjiconstantinou M, Panula P, Lackovic Z, Neff NH. Spinal cord serotonin: a biochemical and immunohistochemical study following transection. Brain Res. 1984;322:245-254. DOI: 10.1016/0006-8993(84)90114-8.

[192] Bregman BS. Development of serotonin immunoreactivity in the rat spinal cord and its plasticity after neonatal spinal cord lesions. Brain Res. 1987;431:245-263. DOI: 10.1016/0165-3806(87)90213-6.

[193] Saruhashi Y, Young W, Perkins R. The recovery of 5-HT immunoreactivity in lumbosacral spinal cord and locomotor function after thoracic hemisection. Exp Neurol. 1996;39:203-213. DOI: 10.1006/exnr.1996.0094. 
[194] Filli L, Zörner B, Weinmann O, Schwab ME. Motor deficits and recovery in rats with unilateral spinal cord hemisection mimic the Brown-Sequard syndrome. Brain. 2011;134:2261-2273. DOI: 10.1093/brain/awr167.

[195] Camand E, Morel MP, Faissner A, Sotelo C, Dusart I. Long-term changes in the molecular composition of the glial scar and progressive increase of serotoninergic fibre sprouting after hemisection of the mouse spinal cord. Eur J Neurosci. 2004;20:11611176. DOI: 10.1111/j.1460-9568.2004.03558.x.

[196] Magnusson T. Effect of chronic transection on dopamine, noradrenaline and 5hydroxytryptamine in the rat spinal cord. Naunyn Schmiedebergs Arch Pharmacol. 1973;278:13-22. DOI: 10.1007/BF00501859.

[197] Jaeger CB, Teitelman G, Joh TH, Albert VR, Park DH, Reis DJ. Some neurons of the rat central nervous system contain aromatic-L-amino-acid decarboxylase but not monoamines. Science. 1983;219:1233-1235. DOI: 10.1126/science.6131537.

[198] Ren LQ, Wienecke J, Hultborn H, Zhang M. Production of dopamine by aromatic Lamino acid decarboxylase cells after spinal cord injury. J Neurotrauma. 2016;33:1-11. DOI: $10.1089 /$ neu.2015.4037.

[199] Hou S, Carson DM, Wu D, Klaw MC, Houlé JD, Tom VJ. Dopamine is produced in the rat spinal cord and regulates micturition reflex after spinal cord injury. Exp Neurol. DOI: 10.1016/j.expneurol.2015.12.001.

[200] Bhattacharyya S, Raote I, Bhattacharya A, Miledi R, Panicker MM. Activation, internalization, and recycling of the serotonin $2 \mathrm{~A}$ receptor by dopamine. Proc Natl Acad Sci USA. 2006;103:15248-15253. DOI: 10.1073/pnas.0606578103. 
